NBER WORKING PAPER SERIES

\title{
SCALE AND SCOPE ECONOMIES IN THE GLOBAL ADVERTISING AND MARKETING SERVICES BUSINESS
}

\author{
Alvin J. Silk \\ Ernst R. Berndt \\ Working Paper 9965 \\ http://www.nber.org/papers/w9965
NATIONAL BUREAU OF ECONOMIC RESEARCH
1050 Massachusetts Avenue
Cambridge, MA 02138
September 2003

An earlier version of this paper was presented at "Globalization of Markets" Colloquium, Harvard Business School, May 28-30, 2003. For assistance in obtaining data, we thank Barbara Esty, David Doft, and Lauren Rich Fine and their staffs at Baker Library, CIBC, and Merrill Lynch, respectively. We are also indebted to Masako Egawa and Yumi Sudo at HBS' Japan Research Office, Tokyo for their help in collecting data. The encouragement and advice of John Quelch is gratefully acknowledged, as is the support of the Division of Research, Harvard Business School. A special note of thanks is due to members of the "Harvard/MIT Advertising Agency Research Seminar" for valuable discussions, especially Charles King, Tuba Ustuner and Andrew von Nordenflycht. The usual disclaimer applies. We dedicate this paper to the memory of Diane D. Wilson. The views expressed herein are those of the authors and not necessarily those of the National Bureau of Economic Research.

(C)2003 by Alvin J. Silk and Ernst R. Berndt. All rights reserved. Short sections of text, not to exceed two paragraphs, may be quoted without explicit permission provided that full credit, including $(\mathrm{C}$ notice, is given to the source. 
Scale and Scope Economies in the Global Advertising and Marketing Services Business Alvin J. Silk and Ernst R. Berndt

NBER Working Paper No. 9965

September 2003

JEL No. L1, L2, L8, M3

\section{ABSTRACT}

We assess size and scope-related economies in the global advertising and marketing services business. A translog cost function is employed wherein a firm's costs vary according to its scale and two dimensions of the scope of its operations. Parameters of the model are estimated via three stage least squares using annual data for 1989-2001 for an unbalanced panel consisting of the eight largest firms in this industry.

A firm's total variable costs are affected by its scale, scope (mix of services and markets served), and by the interaction of the two dimensions of scope. The latter effect suggests that economies of coordination may accompany the strategy of jointly offering advertising and marketing services globally. Estimates indicate that the industry's long-run cost function is subject to very slight economies of scale. Diseconomies of scale accompany growth in volume obtained by extending either breadth of service offerings or market coverage. A small cost advantage, typically of one to two percent, is uniformly associated with joint production of services for the domestic and overseas markets, as compared to splitting up the firm into smaller stand-alone entities. Scope economies of a similar magnitude arise consistently from the joint production of advertising and marketing services.

Alvin J. Silk

Graduate School of Business Administration Harvard University

Soldiers Field

Boston, MA 02163

asilk@hbs.edu
Ernst R. Berndt

Sloan School of Management

Massachusetts Institute of Technology

50 Memorial Drive

Cambridge, MA 02141-1347

and NBER

eberndt@mit.edu 


\section{SCALE AND SCOPE ECONOMIES IN THE GLOBAL ADVERTISING AND MARKETING SERVICES BUSINESS}

Alvin J. Silk and Ernst R. Berndt

\section{INTRODUCTION}

The large body of theoretical and empirical studies on the economics of advertising has tended to focus almost exclusively on issues relating to the amounts firms expend for advertising and the effects those outlays have on consumers and competition. For an extensive review, see Bagwell (2002). However, analysis of the "production" side of advertising has been largely neglected by economists. Over the past two decades the organization of the advertising and marketing services business has undergone a major structural change. In response to shifts in client demand, advertising agencies in search of growth have globalized and diversified their services. Concurrently, after long maintaining a diverse and unconcentrated size structure, the advertising agency and marketing services business has become more consolidated, with publicly-owned holding companies now dominating this industry.

Despite these developments, there has been surprisingly little empirical study of the economics of firms engaged in the production of global advertising and marketing services. The purpose of this paper is to address that void. How important are scale and scope economies in the global advertising and marketing services business? Much of the rationale underlying the growth strategies of these organizations emphasizes size-related advantages (Elliot 2002). At the same time, whether global firms possess a sustainable competitive advantage over smaller, regional players is the subject of an ongoing debate within the industry (Anholt 2000). Several waves of mergers and acquisitions have fueled concerns about the rising concentration level in the industry (Kim 1995). The holding company model employed by global firms has also recently 
come under renewed scrutiny (Cardona 2002b, Khermouch 2003). For all these reasons then, the issue of size-related economies in this industry is one deserving empirical analysis. To the best of our knowledge, this is the first econometric study of such cost economies

We treat holding companies as multiproduct firms and estimate a translog model of firm costs applying three-stage least squares to a time series of annual data for an unbalanced panel consisting of the eight leading global advertising and marketing services firms. Collectively this group of holding companies accounted for more than ninety percent of the estimated total revenue earned in 2001 by the hundred largest firms in this industry.

Our results can be briefly summarized. We demonstrate that a firm's costs are affected by its size, scope (mix of services offered and markets served) and the interaction of the latter two dimensions of firm scope. The presence of the interaction effect supports a major but controversial element of holding company strategy; namely, that coordination economies are available from the delivery of integrated advertising and marketing services globally. Using the parameter estimates for the translog cost function, we then investigate the extent to which overall scale economies/diseconomies and product-specific scale and scope economies/diseconomies are available to firms in this industry. Our estimates indicate that the industry's long-run cost function is subject to very slight economies of scale. Growth obtained by extending either the breadth of services offered or market coverage is accompanied by diseconomies of scale, a result we show not to be inconsistent with the existence of overall or global economies of scale. These findings do not point to any substantial level of potential scale economies that remains to be exploited by the largest firms in this industry. Such findings are to be expected in a highly competitive industry with relatively low fixed costs. 
Small scope economies involving cost savings of one to two percent are realized through diversification of either lines of business or market coverage. The institutional constraint arising from the longstanding industry norm that prohibits an agency from serving competing accounts that Silk and Berndt (1995) hypothesized to limit the growth and diversification potential of traditional full service advertising agencies appears to have been obviated by the holding company form of organization.

The paper is organized as follows. Section II discusses the global advertising and marketing services business and the holding company form of organization used by firms in this industry. Section III sets forth the econometric model and method employed here along with measures of scale and scope economies. In Section IV, the database is described and estimation results are presented. Section V summarizes our findings on scale and scope economies. Section VI discusses implications of the results and possible limitations and extensions of the present study. Section VII presents our conclusions.

\section{THE GLOBAL ADVERTISING AND MARKETING SERVICES BUSINESS}

\section{II.1. Globalization of Advertising and Marketing Services}

The beginning of the internationalization of the advertising and marketing services industry dates back at least as far as 1899 when J. Walter Thompson opened an office in London (West 1987). In 1927 Thompson became General Motors' "export agency" and embarked on a rapid international expansion. In the late 1920's and early 1930's, Thompson opened thirty-four branch offices in Europe, the Middle East, South Africa, India, Australia, and South America (Merron 1999). Thompson was not GM's domestic agency and its appointment on the export account lasted only five years. Interestingly, Merron (1999, p. 469) observed: "the key to the branch offices' survival was that they aggressively pursued local clients." Weinstein (1974) 
traced the international expansion of fifteen U.S. agencies over the period 1915-1971 and found that the rate at which agencies opened offices in countries for the first time almost quadrupled over the period 1960-1971.

Comparatively little appears to have been written about the international expansion of Asian or European agencies. A notable exception is West's (1988) insightful study of multinational competition in the British advertising agency business over the period 1936-1987. West's analysis identified two distinct phases of development. The first, beginning in the interwar period and lasting until the late 1970's, is characterized- as the "Americanization of British advertising." The share of total advertising billings in the U.K. held by U.S. multinational agencies grew from thirteen percent in 1936, peaking at forty-two percent in 1970. Unlike the U.S., the agency business in Britain has long been a highly concentrated industry. The billings share of the ten largest agencies was seventy percent in 1936 and reached eighty-two percent in 1970. The pioneering U.S. agencies in the U.K. were greenfield entrants following the multinational growth path of their U.S-based clients. Reciprocal alliances between American and British agencies became commonplace in the interwar period. Later in the post-World War II period, West shows that acquisitions became important, noting that between 1957 and 1967, U.S. agencies purchased thirty-two British agencies.

The second phase of West's historical analysis covers the comeback of the British. The share of U.K. billings held by U.S. multinational agencies fell from a high of forty-two percent in 1970, to 34 per cent in 1980 and 22 per cent in 1987. The major developments in this period were the aggressive growth and stunning success, at home and abroad, of two London-based firms: first, Saatchi \& Saatchi (beginning in the late 1970's); and then WPP, in the late 1980's. West (1988) contrasts the advantage exploited by the British in their domestic comeback and 
international expansion with that of the earlier American penetration of the high end of the U.K. market:

The advantage accruing to British advertising agencies in the changing trends in foreign direct investment flows in the 1980's was different from that previously held by the Americans.It provided access to capital, rather than to the patronage of large advertisers. Throughout the entire period, British agencies have never been able to exploit the indigenous British-based MNE advertiser in the same way that U.S. agencies have used American MNEs (p. 487).

West argues that Saatchi \& Saatchi's domestic success inspired confidence within the British financial community, giving advertising agencies improved access to capital and permitting them to grow by means of acquisitions: "The new ease in raising capital facilitated the spectacular entrance of British multinational advertising agencies into the American domestic market from 1982 onward" (p. 499). That advance was marked by two highly publicized deals: Saatchi \& Saatchi's acquisition of New York-based Ted Bates Worldwide in May 1986, and WPP's takeover of J. Walter Thompson in June 1987.

In the next section, we consider the dominant organization form that the industry has adopted in pursuit of growth and globalization, namely, the public holding company.

\section{II.2. The Holding Company Concept}

The world's largest advertising and marketing services firms are all public holding companies that own (partially or outright) numerous operating companies offering a wide variety of related and/or competing services to clients. To varying degrees, the parent organization performs a coordinating role and supplies subsidiary organizations with support programs, systems, and resources. However, as the chief financial officer of a leading firm in this industry was recently quoted as saying: "There is no single model for a successful holding company. Their success depends on how they perform their functions, whether as a hands-off financial entity or a structure to help networks work together" (Cardona 2002b). 
The pioneering global advertising and marketing services holding company is the Interpublic Group of Companies. Marion Harper, who served as its Chairman and CEO throughout the 1960 's, is widely acknowledged to have been the architect of this organizational innovation. Harper saw adherence to the industry's longstanding norm that an agency not serve competitors in the same category of business as a major impediment to achieving the twin goals of growth and diversification (American Association of Advertising Agencies 1979). He proposed the holding company concept as a means of circumventing that stricture. His biographer and colleague reported Harper as having said: “I don't see why it shouldn't be possible for us to own more than one agency and serve competing accounts, as long as we keep the two agencies completely separate" Johnson (1982, p. 96). Despite initial resistance from clients and criticism from competitors, Harper eventually prevailed and the holding company concept gained acceptance and spread.

Silk and Berndt (1995) analyzed the industry norm on conflict policy as an institutional mobility barrier (in the sense of Caves and Porter (1977)) that induces individual agencies to grow by diversifying their lines of service offerings rather than by expanding existing ones. A second institutional factor identified by Silk and Berndt (1995) as affecting agency growth and diversification strategies of advertising agencies was the industry practice of agencies bundling creative and media services, a strategy encouraged by the fact that it is customary for clients to advertise simultaneously in several media. Based on these two considerations, Silk and Berndt (1995, p. 439) advanced the hypothesis of "excessive" diversification: "the joint presence of media bundling on the demand side and conflict policy on the supply side constitute institutional constraints that induce firms to diversify more extensively than might otherwise be cost justified." Consistent with this hypothesis, in a cross-sectional analysis of 1987 data for 401 U.S. 
advertising agencies, Silk and Berndt (1995) found that media-specific scope economies were negatively related to agency size.

Silk and Berndt's (1995) analysis and empirical study were conducted at the level of individual advertising agencies, rather than that of holding companies. Two important structural changes have occurred since 1987, the year of the data Silk and Berndt utilized. First, over the past two decades there has been a growing tendency for advertising agencies to unbundle their services as multi-product clients have sought to gain bargaining power with media suppliers by consolidating media buying for their brands in organizations specializing in media planning and buying (Horsky 2002). Secondly, all of the major holding companies have established media planning and buying units that are available to perform these functions for clients of the networks of agencies controlled by the holding companies (Mandese 2002). Thus, it may be these changes have allowed holding companies to obviate the disadvantage of excessive diversification Silk and Berndt (1995) argued as being present at the level of individual agencies in 1987.

Holding company management face an ongoing challenge to achieve a balance between policies that favor centralization in ways that may improve coordination and profitability, versus those that allow decentralization in order to foster creativity and maintain credibility with clients as to the independence of individual organizations. For example, Omnicom has the reputation for granting considerable autonomy to its operating divisions (Elliot 2002). WPP is one of the organizations studied by Raynor and Bower (2001) in their research on how strategic integration is accomplished in contemporary diversified companies facing dynamic and uncertain environments. They observe that WPP has been successful in building a strategically flexible 
organization by pursuing different degrees of relatedness among the operating divisions, some being closely linked, others less so. See Bower and Hunt (2001) for details.

Based on Advertising Age's estimates of holding companies worldwide gross incomes, the annual nominal growth rate of the world's ten largest holding companies averaged almost thirteen per cent over the twelve year period, 1990-2001. This growth is almost three times greater than the growth rate of worldwide expenditures for advertising and marketing services that averaged only four and a half percent over the same time period. ${ }^{1}$

Scale and scope economies figure prominently in the reports of investment analysts who follow this industry closely, especially with respect to how cost economies relate to the basic elements of firm strategy (growth, globalization, diversification) and industry consolidation. Among the major industry trends emphasized by Doft et al. (2002) are client demand for integrated marketing services and cross national consistency in brand communications, as well as interest in consolidating the multiplicity of accounts with fewer service suppliers. Fine et al. (2003) point out that the growth rate and margins of marketing services tend to be greater than those for advertising-related services. However, they see size-related improvements in margins as being difficult to realize, in part because of client cost-consciousness and bargaining power. Diversification with respect to both lines of service offered and markets served may also affect the sensitivity of holding companies' performance to the business cycle. However, Fine et al. (2003) note that diversification can serve not only to dampen downturns, but may also limit speed of recoveries.

Against this background, we move on to a discussion of the modeling framework and analytical methods used in our empirical study.

1 This growth rate calculation was based on WPP's estimates of the size of the worldwide marketing communications expenditures presented each year in their annual report. 


\section{III.ECONOMETRIC MODEL AND METHOD}

We begin this section with the specification of the cost function employed in the empirical analysis. Definitions of the measures of scale and scope economies reported later are then presented along with expressions for estimating them in terms of the variables and parameters of the translog cost function. Detailed derivations are given in Appendix A.

\section{III.1. Model Specification}

We employ a translog (transcendental logarithmic) model to represent a firm's total variable costs of producing its output of services. Widely used in empirical econometrics, the translog model is a "flexible" functional form that can be used to capture a variety of size-related cost phenomena arising from the operations of multiproduct firms, including in particular, scale and scope effects (Berndt 1991, Paul 1999). The translog cost function for firm i $(\mathrm{i}=1, \ldots, \mathrm{k})$ may be written as follows:

$$
\ln \mathrm{TVC}_{\mathrm{i}}=\ln \alpha_{\mathrm{i}+} \beta_{1} \ln \mathrm{Y}_{\mathrm{i}}+1 / 2 \beta_{2}\left(\ln \mathrm{Y}_{\mathrm{i}}\right)^{2}+\gamma \mathrm{M}_{\mathrm{id}}+\delta \mathrm{P}_{\mathrm{ia}}+\theta \mathrm{M}_{\mathrm{id}} \mathrm{P}_{\mathrm{ia}}
$$

where:

$$
\begin{aligned}
\mathrm{TVC}_{\mathrm{i}}= & \text { total variable cost } \\
\mathrm{Y}_{\mathrm{i}}= & \text { a measure of the scale of total output } \\
\mathrm{M}_{\mathrm{id}}= & \text { share of firm's output }(\mathrm{Y}) \text { produced for the U.S. market, rather than for the } \\
& \text { overseas' markets, }\left(1-\mathrm{M}_{\mathrm{id}}\right), \mathrm{M}_{\mathrm{id}} \leq 1
\end{aligned}
$$

where $\alpha_{i}, \beta_{1}, \beta_{2}, \gamma, \delta$, and $\theta$ are parameters to be estimated. 
Now the firm's average variable cost $\left(\mathrm{AVC}_{\mathrm{i}}\right)$ is given by:

$$
\begin{aligned}
\ln \mathrm{AVC}_{\mathrm{i}} & =\ln \left(\mathrm{TVC}_{\mathrm{i}} / \mathrm{Y}_{\mathrm{i}}\right)=\ln \mathrm{TVC}_{\mathrm{i}}-\ln \mathrm{Y}_{\mathrm{i}} \\
& =\ln \alpha_{\mathrm{i}}+\left(\beta_{1}-1\right) \ln \mathrm{Y}_{\mathrm{i}}+1 / 2 \beta_{2}\left(\ln \mathrm{Y}_{\mathrm{i}}\right)^{2}+\gamma \mathrm{M}_{\mathrm{id}}+\delta \mathrm{P}_{\mathrm{ia}}+\theta \mathrm{M}_{\mathrm{id}} \mathrm{P}_{\mathrm{ia}}
\end{aligned}
$$

This specification of the translog cost model allows for the possibility of both scale and scope effects. Depending on the signs and magnitudes of the scale parameters, $\beta_{1}$ and $\beta_{2}$, the AVC function may be either everywhere decreasing or U-shaped in Y.

The two potentially important sources of scope effects discussed in Section II are represented in the translog cost function. The first arises from how a firm's total output is distributed across the regional markets it serves. We attempt to capture this effect by treating the global market as a dichotomy, consisting of a domestic (U.S.) segment and a composite "overseas" market. These account for $\mathrm{M}_{\mathrm{id}}$ and $\left(1-\mathrm{M}_{\mathrm{id}}\right)$ of the firm's total output, respectively.

The other dimension of scope relates to the composition of the firm's output with respect to its lines of business or products/services. We treat a firm's output as consisting of either "advertising" or "other marketing" services, representing $\mathrm{P}_{\mathrm{ia}}$ and (1- $\left.\mathrm{P}_{\mathrm{ia}}\right)$, respectively, of its total output. Note that the definitions treat these two dimensions of the firm's scope as completely separate from one another.

The final term of (2) is the cross-product of the shares of firm output accounted for by the domestic (U.S.) market $\left(\mathrm{M}_{\mathrm{id}}\right)$ and advertising services $\left(\mathrm{P}_{\mathrm{ia}}\right)$, respectively. This interaction term allows for the two dimensions of scope to affect costs jointly as well as separately. A negative sign on the coefficient for this interaction term would be consistent with the view that firms may realize a cost-reducing benefit through their pursuit of a key feature of their business strategies, that of providing global clients with "one stop shopping" for a broad array of advertising and marketing services (Lawrence 2000). Economies of coordination may be achieved through 
exploiting synergies in delivering a variety of services to a geographically dispersed client base that are not available when operations are more specialized and localized. Alternatively, firms may incur additional coordination costs in providing global clients with an array of services that are absent in more specialized and localized operations. Even when economies of coordination are available, they may be bargained away in negotiating compensation and service levels with clients (Fine et al., 2003). Such conditions would suggest that "one stop shopping" could raise costs and lead to a positively-signed coefficient for the interaction term. Thus, a priori, it is not clear whether the expected sign for the coefficient of the cross-product of the share terms for the two dimensions of scope should be positive or negative.

We now turn to defining explicit measures of scale and scope effects.

\section{III.2. Scale Economies}

In traditional economic theory, the firm produces a single product, and in such cases returns to scale are measured by the inverse of the elasticity of total cost with respect to output: the percentage change in total cost associated with a one percent increase in output (cf. Pindyck and Rubinfeld 1995). The returns-to-scale measure is also equal to the ratio of average cost to marginal cost.

In the case of a multiproduct or multi-service firm, the notion of average cost is not welldefined since the mix of outputs may change with overall size. To circumvent this problem, returns to scale are defined in terms of the effects on total cost when all the service outputs are increased proportionately, i.e., holding the mix of service outputs constant. This concept is referred to as global or ray returns to scale (Bailey and Friedlander 1982) and in the present context is defined as:

$$
\mathrm{RRS}_{\mathrm{i}}=\left(\mathrm{TVC}_{\mathrm{i}} / \mathrm{Y}_{\mathrm{i}}\right) /\left(\partial \mathrm{TVC}_{\mathrm{i}} / \partial \mathrm{Y}_{\mathrm{i}}\right) \text {, evaluated at } \mathrm{M}_{\mathrm{id}}=\mathrm{M}_{\mathrm{id}}^{*}, \mathrm{P}_{\mathrm{ia}}=\mathrm{P}^{*}{ }_{\mathrm{ia}}
$$


For our translog cost model (1), it is readily shown that:

$$
\begin{aligned}
\partial \ln \mathrm{TVC}_{\mathrm{i}} / \partial \ln \mathrm{Y}_{\mathrm{i}} & =\left(\partial \mathrm{TVC}_{\mathrm{i}} / \partial \mathrm{Y}_{\mathrm{i}}\right)\left(\mathrm{Y}_{\mathrm{i}} / \mathrm{TVC}_{\mathrm{i}}\right) \\
& =\beta_{1}+\beta_{2} \ln \mathrm{Y}_{\mathrm{i}}
\end{aligned}
$$

Re-arranging terms, we obtain:

$$
\operatorname{RRS}_{\mathrm{i}}=1 /\left(\beta_{1}+\beta_{2} \ln \mathrm{Y}_{\mathrm{i}}\right)
$$

When there are economies of scale, total cost (TVC) increases less than proportionately with output $(\mathrm{Y})$, marginal cost $(\partial \mathrm{TVC} / \partial \mathrm{Y})$ is less than average cost (TVC/Y), both of which are declining in $\mathrm{Y}$, and RRS is greater than one. When there are diseconomies of scale, marginal cost exceeds average cost, and RRS is less than one.

Another measure of scale economies that is particularly useful for the multiproduct or multi-service firms is that of product-specific scale economies (Bailey and Friedlander 1982). In the present context, one may view a firm as producing two types of outputs: advertising-related services (denoted by the subscript a) and other marketing services (m). We assume that the mix of domestic (U.S.) and overseas volume is the same for both types of services and equal to the share, $\mathrm{M}_{\mathrm{id}}$, and $\left(1-\mathrm{M}_{\mathrm{id}}\right)$, respectively so that the composition of the firm's total volume in terms of markets served is unchanged.

$\mathrm{SCL}(\mathrm{MS})_{\mathrm{i}}$, is then defined as the ratio of average incremental cost, $\mathrm{AIC}_{\mathrm{im}}$, to the marginal cost, $\mathrm{MC}_{\mathrm{im}}$ of producing other marketing services (m), in addition to advertising (a):

$$
\mathrm{SCL}(\mathrm{MS})_{\mathrm{i}}=\mathrm{AIC}_{\mathrm{im}} / \mathrm{MC}_{\mathrm{im}}
$$

where average incremental cost $\left(\mathrm{AIC}_{\mathrm{im}}\right)$ is defined as the incremental cost of adding other marketing services to firm previously producing only advertising-related services, 


$$
\mathrm{AIC}_{\mathrm{im}}=\left[\mathrm{TVC}\left(\mathrm{Y}_{\mathrm{i}}\right)-\mathrm{TVC}\left(\mathrm{Y}_{\mathrm{ia}}\right)\right] / \mathrm{Y}_{\mathrm{im}},
$$

with $\mathrm{Y}_{\mathrm{i}}=\mathrm{Y}_{\mathrm{ia}}+\mathrm{Y}_{\mathrm{im}}$

and where $\operatorname{TVC}\left(\mathrm{Y}_{\mathrm{i}}\right)$ is the total variable cost of producing both advertising and other marketing services as defined above by (1). TVC $\left(\mathrm{Y}_{\mathrm{ia}}\right)$ is the total variable cost of producing only advertising-related services (with $Y_{i a}=P_{i a} Y_{i}$ ) and $Y_{i m}=\left(1-P_{i a}\right) Y_{i}$ is output of other marketing services. $\mathrm{MC}_{\mathrm{im}}$ is marginal cost is defined as $\partial \mathrm{TVC}\left(\mathrm{Y}_{\mathrm{i}}\right) / \partial \mathrm{Y}_{\mathrm{im}}$.

For the multiproduct cost function (1), SCL(MS)i turns out to be (see Appendix A for details of the derivation):

$$
\begin{aligned}
& {\left[\exp \left\{\ln \alpha_{\mathrm{i}}+\beta_{1} \ln \mathrm{Y}_{\mathrm{i}}+1 / 2 \beta_{2}\left(\ln \mathrm{Y}_{\mathrm{i}}\right)^{2} \gamma \mathrm{M}_{\mathrm{id}}+\delta \mathrm{P}_{\mathrm{ia}}+\theta \mathrm{M}_{\mathrm{id}} \mathrm{P}_{\mathrm{ia}}\right\}\right.} \\
& \left.-\exp \left\{\ln \alpha_{\mathrm{i}}+\beta_{1} \ln \left(\mathrm{P}_{\mathrm{ia}} \mathrm{Y}_{\mathrm{i}}\right)+1 / 2 \beta_{2}\left(\ln \mathrm{P}_{\mathrm{ia}} \mathrm{Y}_{\mathrm{i}}\right)^{2}+(\gamma+\theta) \mathrm{M}_{\mathrm{id}}+\delta\right\}\right]
\end{aligned}
$$

$\operatorname{SCL}(\mathrm{MS})_{\mathrm{i}}=$

$$
\begin{gathered}
{\left[\{ \beta _ { 1 } + \beta _ { 2 } \operatorname { l n } Y _ { \mathrm { i } } \} \operatorname { e x p } \left\{\ln \alpha_{\mathrm{i}}+\beta_{1} \ln \mathrm{Y}_{\mathrm{i}}+1 / 2 \beta_{2}\left(\ln \mathrm{Y}_{\mathrm{i}}\right)^{2}+\gamma \mathrm{M}_{\mathrm{di}}\right.\right.} \\
\left.\left.+\delta \mathrm{P}_{\mathrm{i}}+\theta \mathrm{M}_{\mathrm{di}} \mathrm{P}_{\mathrm{i}}\right\}\right]
\end{gathered}
$$

The above analysis may be viewed as assessing the scale economies associated with adding "other marketing services" to the firm's existing offering of advertising-related services. Such an analysis is meaningful in that it reflects the growth path of our sample of firms. Historically, these firms were initially full service advertising agencies and over time expanded their operations to include other marketing services.

In our scale economy calculations we assume that the mix of U.S. and overseas volume is the same for both types of services and equal to that for the firm's total output, as given by $\mathrm{M}_{\mathrm{id}}$. Note that for a dichotomous scope variable, the sign of its coefficient in the cost model (1) and the expression above (8) for product-specific scale economies are both sensitive to the manner in which the dichotomous scope variable is defined, i.e., $\mathrm{P}_{\mathrm{ia}}$ vs. (1- $\left.\mathrm{P}_{\mathrm{ia}}\right)$ and $\mathrm{M}_{\mathrm{id}}$ vs. $\left(1-\mathrm{M}_{\mathrm{id}}\right)$. 
It is also of interest to assess the scale economies associated with becoming "global" by adding the volume sold in the overseas market $\left(\left[1-\mathrm{M}_{\mathrm{id}}\right] \mathrm{Y}_{\mathrm{i}}\right)$ to that for the domestic (U.S.) market $\left(\mathrm{M}_{\mathrm{id}} \mathrm{Y}_{\mathrm{i}}\right)$. For these calculations, we assume that the mix of advertising and marketing services is the same for both the domestic (U.S.) and overseas markets and equal to the share of the firm's total output of advertising and marketing services, as given by $\mathrm{P}_{\mathrm{ia}}$, and (1- $\left.\mathrm{P}_{\mathrm{ia}}\right)$, respectively.

We define a product-specific index of scale economies, $\mathrm{SCL}(\mathrm{OV})_{\mathrm{i}}$ associated with extending operations from the domestic (U.S.) market (d) to the overseas market (denoted by the subscript o). $\mathrm{SCL}(\mathrm{OV})_{\mathrm{i}}$ is the ratio of average incremental cost, $\mathrm{AIC}_{\mathrm{io}}$, to the marginal cost, $\mathrm{MC}_{\mathrm{io}}$ of producing the volume sold in the overseas market (o) in addition to that being sold in the domestic market (d):

$$
\operatorname{SCL}(\mathrm{OV})_{\mathrm{i}}=\mathrm{AIC}_{\mathrm{io}} / \mathrm{MC}_{\mathrm{io}} \text {, }
$$

where average incremental cost $\left(\mathrm{AIC}_{\mathrm{io}}\right)$ is defined as the incremental cost associated with producing for the overseas market incurred by a firm previously producing only for the domestic (U.S.) market:

$$
\begin{aligned}
\operatorname{AIC}_{\mathrm{io}} & =\left[\operatorname{TVC}\left(\mathrm{Y}_{\mathrm{i}}\right)-\operatorname{TVC}\left(\mathrm{Y}_{\mathrm{id}}\right)\right] / \mathrm{Y}_{\mathrm{io}}, \\
\text { with } \mathrm{Y}_{\mathrm{i}} & =\mathrm{Y}_{\mathrm{id}}+\mathrm{Y}_{\mathrm{io}},
\end{aligned}
$$

where $\operatorname{TVC}\left(\mathrm{Y}_{\mathrm{i}}\right)$ is the total variable cost of producing the volumes sold in both the domestic (U.S.) and overseas markets as defined by (1) above. In this context, $\operatorname{TVC}\left(\mathrm{Y}_{\mathrm{id}}\right)$ is the total variable cost of producing only the volume sold in domestic (U.S.) market $\left(\mathrm{Y}_{\mathrm{id}}=\mathrm{M}_{\mathrm{id}} \mathrm{Y}_{\mathrm{i}}\right)$ and $\mathrm{Y}_{\mathrm{io}}=\left(1-\mathrm{M}_{\mathrm{id}}\right) \mathrm{Y}_{\mathrm{i}}$ is the output sold overseas. $\mathrm{MC}_{\mathrm{io}}$ is marginal cost and is defined as $\partial \mathrm{TVC}\left(\mathrm{Y}_{\mathrm{i}}\right)$ / $\partial \mathrm{Y}_{\mathrm{io}}$.

For the multiproduct cost function (1), $\mathrm{SCL}_{\mathrm{io}}$ may be shown to be (see Appendix A for details of the derivation): 


$$
\begin{aligned}
& {\left[\exp \left\{\ln \alpha_{\mathrm{i}}+\beta_{1} \ln \mathrm{Y}_{\mathrm{i}}+1 / 2 \beta_{2}\left(\ln \mathrm{Y}_{\mathrm{i}}\right)^{2}+\gamma \mathrm{M}_{\mathrm{id}}+\delta \mathrm{P}_{\mathrm{ia}}+\theta \mathrm{M}_{\mathrm{id}} \mathrm{P}_{\mathrm{ia}}\right\}\right.} \\
& \left.-\exp \left\{\ln \alpha_{\mathrm{i}}+\beta_{1} \ln \left(\mathrm{M}_{\mathrm{id}} \mathrm{Y}_{\mathrm{i}}\right)+1 / 2 \beta_{2}\left(\ln \mathrm{M}_{\mathrm{id}} \mathrm{Y}_{\mathrm{i}}\right)^{2}+(\delta+\theta) \mathrm{P}_{\mathrm{ia}}+\gamma\right\}\right]
\end{aligned}
$$

$\operatorname{SCL}(\mathrm{OV})_{\mathrm{i}}=$

$$
\begin{gathered}
{\left[\{ \beta _ { 1 } + \beta _ { 2 } \operatorname { l n } \mathrm { Y } _ { \mathrm { i } } \} \operatorname { e x p } \left\{\ln \alpha_{\mathrm{i}}+\beta_{1} \ln \mathrm{Y}_{\mathrm{i}}+1 / 2 \beta_{2}\left(\ln \mathrm{Y}_{\mathrm{i}}\right)^{2}+\gamma \mathrm{M}_{\mathrm{id}}\right.\right.} \\
\left.\left.+\delta \mathrm{P}_{\mathrm{ia}}+\theta \mathrm{M}_{\mathrm{id}} \mathrm{P}_{\mathrm{ia}}\right\}\right]
\end{gathered}
$$

Note that SCL(MS) $)_{\mathrm{i}}$ and $\mathrm{SCL}(\mathrm{OV})_{\mathrm{i}}$ may differ because in general, $\mathrm{TVC}\left(\mathrm{Y}_{\mathrm{ia}}\right) \neq \mathrm{TVC}\left(\mathrm{Y}_{\mathrm{id}}\right)$. The manner in which both $\mathrm{AIC}_{\mathrm{io}}$ and $\mathrm{MC}_{\mathrm{io}}$ are defined above assumes that a firm expands operations from its "home base" in the U.S. to serve the "overseas" market. As will become apparent in section IV.2 below, this assumption is consistent with the operational definition of the scope variable for "markets served" as the share of output arising from U.S. operations used later in the estimation of the cost model (Equation (1)). Analysis of product-specific scale economies associated with expansion from a home base in the U.S. to the overseas market conforms to the history of four of our sample of eight firms identified in Section IV.1 that follows (Grey, Interpublic, Omnicom, and WPP). However, the historical growth paths of the other four firms were different. In the cases of the other four firms in our sample (Cordiant, Dentsu, Havas, and Publicis), their operations were initially in overseas markets and later expanded to the U.S. Hence for the latter firms, $\mathrm{SCL}(\mathrm{OV})_{\mathrm{i}}$ as defined in (9) and (11), does not have an historically meaningful and comparative interpretation. For this reason, we report estimates of SCL(OV) $)_{i}$ only for the former four firms (Grey, Interpublic, Omnicom, and WPP).

\section{III.3. $\quad$ Scope Economies}

Scope economies arise when cost savings are realized from producing multiple services and/or from serving multiple markets rather than splitting up the firm into separate smaller entities, each producing just one service and/or serving a single market. See Bailey and 
Friedlander 1982 for a detailed discussion of the distinction between scale and scope economies in a multiproduct firm, as well as references to the literature.

To measure the degree to which there are scope economies in the case at hand, we estimate the percentage of the total variable cost of production that is saved when the advertising-related and other marketing services are produced jointly by the same firm rather than produced by two stand-alone firms. As in the case of scale economies discussed in III.2, we consider two alternative ways of splitting production: according to either: (a) service mix, advertising-related versus other marketing services; or (b) market served, U.S. versus overseas.

Consider first cost savings that arise from joint rather than stand-alone production of different lines of business, i.e., components of the service mix. For that split, returns to scope $\left(\mathrm{RSPLB}_{\mathrm{i}}\right)$ or the percentage cost savings realized from joint versus individual production is:

$$
\operatorname{RSP}(L B)_{i}=\left[\operatorname{TVC}\left(Y_{i a}\right)+\operatorname{TVC}\left(Y_{i m}\right)-\operatorname{TVC}\left(Y_{i}\right)\right] / \operatorname{TVC}\left(Y_{i}\right)
$$

When economies of scope are present, the joint cost, $\operatorname{TVC}\left(\mathrm{Y}_{\mathrm{i}}\right)$, is less than the sum of the individual costs, $\operatorname{TVC}\left(\mathrm{Y}_{\mathrm{ia}}\right)+\mathrm{TVC}\left(\mathrm{Y}_{\mathrm{im}}\right)$, and $\mathrm{RSP}\left(\mathrm{LB}_{\mathrm{i}}\right)$ is greater than zero. If the joint cost exceeds the sum of the stand-alone costs, $\operatorname{RSP}\left(\mathrm{LB}_{\mathrm{i}}\right)$ is negative and there are diseconomies of scope.

For the multiproduct cost function (1), it can be shown that (see Appendix A for details):

$$
\operatorname{RSP}(L B)_{i}=\frac{\begin{array}{l}
{\left[\exp \left\{\ln \alpha_{i}+\beta_{1} \ln P_{a i} Y_{i}+1 / 2 \beta_{2}\left(\ln P_{i a} Y_{i}\right)^{2}+(\gamma+\theta) M_{i d}+\delta\right]\right.} \\
+\left[\exp \left\{\ln \alpha_{i}+\beta_{1} \ln \left(1-P_{i a}\right) Y_{i}+1 / 2 \beta_{2}\left(\ln \left(1-P_{i a}\right) Y_{i}\right)^{2}+\gamma M_{i d}\right]\right.
\end{array}-}{\left[\exp \left\{\ln \alpha_{i}+\beta_{1} \ln Y_{i}+1 / 2 \beta_{2}\left(\ln Y_{i}\right)^{2}+\gamma M_{i d}+\delta P_{i a}+\theta M_{i d} P_{i a}\right\}\right]}
$$

For the alternative stand-alone split based on market served, returns to scope, RSP(GL), the percentage cost savings gained from joint versus stand-alone production is: 


$$
\left.\operatorname{RSP}(G L)_{i}=\left[\operatorname{TVC}\left(Y_{i d}\right)+\operatorname{TVC}\left(Y_{i o}\right)-\operatorname{TVC}\left(Y_{i}\right)\right] / \operatorname{TVC}\left(Y_{i}\right)\right]
$$

where $\left[\operatorname{TVC}\left(\mathrm{Y}_{\mathrm{id}}+\mathrm{TVC}\left(\mathrm{Y}_{\mathrm{io}}\right)\right]\right.$ is the sum of the costs of producing the volumes sold in the domestic (U.S.) and overseas markets ( $\mathrm{Y}_{\mathrm{id}}$, and $\mathrm{Y}_{\mathrm{io}}$, respectively), and $\mathrm{TVC}\left(\mathrm{Y}_{\mathrm{i}}\right)$ is the total cost of producing these outputs jointly. As is shown in Appendix A, for the multiproduct cost function (1), RSP(GL) $)_{\mathrm{i}}$ turns out to be:

$$
\operatorname{RSP}(G L)_{\mathrm{i}}=\frac{\begin{array}{c}
{\left[\exp \left\{\ln \alpha_{\mathrm{i}}+\beta_{1} \ln \mathrm{M}_{\mathrm{id}} \mathrm{Y}_{\mathrm{i}}+1 / 2 \beta_{2}\left(\ln \mathrm{M}_{\mathrm{id}} \mathrm{Y}_{\mathrm{i}}\right)^{2}+\gamma+(\delta+\theta) \mathrm{P}_{\mathrm{ia}}\right]\right.} \\
+\left[\exp \left\{\ln \alpha_{\mathrm{i}}+\beta_{1} \ln \left(1-\mathrm{M}_{\mathrm{id}}\right) \mathrm{Y}_{\mathrm{i}}+1 / 2 \beta_{2}\left(\ln \left(1-\mathrm{M}_{\mathrm{id}}\right) \mathrm{Y}_{\mathrm{i}}\right)^{2}+\delta \mathrm{P}_{\mathrm{ia}}\right]\right.
\end{array}}{\left[\exp \left\{\ln \alpha_{\mathrm{i}}+\beta_{1} \ln \mathrm{Y}_{\mathrm{i}}+1 / 2 \beta_{2}\left(\ln \mathrm{Y}_{\mathrm{i}}\right)^{2}+\gamma \mathrm{M}_{\mathrm{id}}+\delta \mathrm{P}_{\mathrm{ia}}+\theta \mathrm{M}_{\mathrm{id}} \mathrm{P}_{\mathrm{ia}}\right\}\right]}-1
$$

Note that RSP(MS) $)_{\mathrm{i}}$ and RSP $(\mathrm{GL})_{\mathrm{i}}$ may differ because in general, $\left[\mathrm{TVC}\left(\mathrm{Y}_{\mathrm{id}}\right)+\right.$ $\left.\mathrm{TVC}\left(\mathrm{Y}_{\mathrm{io}}\right)\right] \neq \mathrm{TVC}\left(\mathrm{Y}_{\mathrm{ia}}\right)+\mathrm{TVC}\left(\mathrm{Y}_{\mathrm{im}}\right)$. We also note in passing that in the case of two products, the measures of global and product-specific scope economies are numerically equivalent.

\section{III.4. Estimation Procedure}

The database available for estimation is an unbalanced panel consisting of a cross section of eight global advertising and marketing service firms with a maximum of thirteen time series observations per firm. For estimation purposes it is convenient to work with (2). To capture the diversity among these firms, we allow $\alpha_{\mathrm{i}}$ in equation (2) to vary cross-sectionally and thus we treat them as fixed effects. The parameters for the scale and scope variables are assumed to be equal across the eight firms. Adding a normally distributed disturbance term to (2), our estimation equation becomes:

$$
\begin{aligned}
\ln \mathrm{AVC}_{\mathrm{it}} & =\ln \alpha_{\mathrm{i}}+\left(\beta_{1}-1\right) \ln \mathrm{Y}_{\mathrm{it}}+1 / 2 \beta_{2}\left(\ln \mathrm{Y}_{\mathrm{it}}\right)^{2}+\gamma \mathrm{M}_{\mathrm{idt}}+\delta \mathrm{P}_{\mathrm{iat}}+\theta \mathrm{M}_{\mathrm{idt}} \mathrm{P}_{\mathrm{iat}}+\mathrm{u}_{\mathrm{it}} \\
\mathrm{i} & =1, \ldots, 8 ; \mathrm{t}=1989, \ldots 2001 .
\end{aligned}
$$


The scale, scope, and interaction explanatory variables are likely to be jointly determined, along with average variable costs. To accommodate this endogeneity, we utilize two types of instruments, each one correlated with the scale, scope, and interaction variables, but not correlated with the random disturbance term in the cost equation. The first instrument is common to all eight firms, and is defined as the growth rate of real worldwide GDP, lagged one year. A second set of instruments varies by firm. The firm-specific variables are the book value of shareholder equity, long-term debt, and tax payments as well as the cross-product of shareholder equity and taxes. Each of these instruments is expressed in constant U.S. dollars, following the convention of using average daily and end-of-the year exchange rates for income statement and balance sheet items, respectively.

Below we report econometric results allowing the scale, scope, and interaction variables to be endogenous using instrumental variable methods. In light of the fact that the firms in our cross section regularly compete directly with one another, contemporaneous correlations in the residuals across firms can be expected. Each firm is therefore treated as a separate equation, in the context of a system of equations framework. Parameter estimates are obtained via three stage least squares (3SLS) that allows for both heteroskedasticity and contemporaneous correlation in the residuals. Assuming the vector of disturbances across the eight firms is multivariate normal, then the parameter estimates for (16) are consistent and asymptotically efficient. See Schmidt (1975) and Wooldridge (2002) for further details. The estimation was executed using EViews 4.0 (2000, Chapt. 19). 


\section{IV.DATABASE AND ECONOMETRIC RESULTS}

\section{IV.1. Cross Section of Global Advertising and Marketing Services Firms}

Our cross section of firms consists of the eight largest Global Advertising and Marketing Services firms, according to Advertising Age's (AA) size rankings of the world's leading “ad organizations" for 2001 (Endicott 2002, p. S10). Table 1 lists the firms alphabetically along with their worldwide gross incomes for 2001 (as presented in their annual reports) and the length of times series for which data were available for use in the analysis.

\section{INSERT TABLE 1}

The absence of publicly available data precluded extending the sample to include additional firms or earlier time periods. For six of the eight firms, thirteen annual observations were available. Only four years of data were available for Cordiant which was not formed until late 1997, following a de-merger from Saatchi \& Saatchi. Reports covering ten years of Havas' history as a public company were obtained. Thus, the maximum number of observations available for estimation purposes was 92. Missing data for certain variables reduced that number of observations available for the econometric analyses undertaken to 83 .

Collectively, these eight firms accounted for 93.9 percent of the combined 2001 gross income of the world's 100 largest ad organization identified by AA. ${ }^{2}$ Although these eight firms dominate the industry's size structure, they differ considerably in scale: a pair of firms (Cordiant and Grey) had gross incomes in 2001 of $\$ 0.9-\$ 1.2$ billion, three mid-range firms (Dentsu,

\footnotetext{
${ }^{2}$ It bears noting that the gross incomes and ranking shown in Table 1 differ from those reported by AA for two reasons. First, in contrast to generally accepted accounting principles (GAAP), AA calculates a parent firm's gross income by weighting the gross incomes of subsidiary organizations according to the percentage of equity owned by the parent. Under GAAP, the parent company reports the income of a subsidiary only when ownership exceeds 50 percent of the subsidiary's equity. Second, AA does not include in gross income revenues derived from several nonadvertising-related services, including public relations and research. See Endicott (2002, p. S-2) for further details.
} 
Havas, and Publicis) earned gross incomes of $\$ 2.2-\$ 2.7$ billion, and three "giants" had gross incomes of $\$ 6-\$ 7$ billion.

\section{IV.2. Definitions of Variables}

Table 2 lists the measures used to operationalize the variables in our translog cost model (1). Firm annual reports were the primary sources of our data. Worldwide gross income (WGI), consisting of commissions and fees paid by clients, has long been recognized as the preferred measure of firm size in the advertising and marketing services industry (Paster 1981). ${ }^{3}$

\section{INSERT TABLE 2}

Total variable costs (TVC) are operating expenses and consist primarily of employee salaries and benefits, plus office expenses. Depreciation and amortization charges were excluded in an effort to reduce inter-firm and or cross-national differences in accounting methods and standards. Average variable cost (AVC) was computed as the ratio of total variable costs to gross income (TVC/WGI). Note that (1-AVC) is equal to the firm's gross margin, a measure routinely monitored and discussed by firm management and industry analysts.

Two dimensions of firm scope, corresponding to markets served and line of services offered, respectively, were treated separately from one another. Each was measured as a dichotomous share of total firm gross income, i.e., share from the U.S. market (USS, (vs. the overseas market, (1-USS)) and share from advertising-related services (ADS, vs. other marketing

\footnotetext{
${ }^{3}$ Agency size is sometimes gauged by the magnitude of its clients" "billings" which include outlays for media space and time, charges for production advertising and promotional material, and the like. Estimates of billings are notoriously suspect as a measure of agency output or scale inasmuch as to varying degrees, they represent "capitalized billings," calculated by capitalizing an agency's gross income at some rate, such as the reciprocal of the commission rate on media expenditures used to compensate a "full service" agency. Over time, capitalized billings have departed from "true" billings as agencies have expanded and unbundled the mix of services they offer and as clients have come to rely more on fee-based, and less on commission-based compensation methods. Cf. Cardona (2002a).
} 
services, such as promotion, public relations, and research, (1-ADS)). Finally, the cross-product term, $\mathrm{XAUS}=$ ADS $\mathrm{x}$ USS, was created as an interaction term for the two dimensions of scope. Systematic measurement error arising from inter-firm and/or cross national differences in accounting methods and standards was mitigated by applying consistent definitions of variables across firms and time. When comparing the quality of our measures, we judge the advertising share, ADS, as the most problematic due to the absence of detail and consistency in reporting the decomposition of gross revenue by lines of services. Both inter-firm differences and intra-firm variability were apparent. Further, this was the one variable that was most likely to be missing from the firm annual reports, particularly in the early phase of our time series. In the interests of preserving degrees of freedom, estimates from external sources were used, as noted in Table 2. To the extent that measurement errors are firm-specific and fixed over time, we capture them by specifying a fixed effect intercept for each firm.

Finally, we attempt to control for any remaining sources of systematic error by treating the intercept term in (2) as a firm fixed effect, thereby allowing the unobserved firm intercept term to be arbitrarily correlated with the explanatory variables (Wooldridge 2002, Chapter 10).

Table 3 presents summary descriptive statistics for the data base. The wide variation present in the scale and scope variables is evident from the diverse values of the median, max, and min. Intercorrelations among the variables used in average cost model are shown in the lower panel of Table 3 . Not unexpectedly, $\mathrm{LWGI}_{\mathrm{it}}$ and $\left(\mathrm{LWGI}_{\mathrm{it}}\right)^{2}$ are virtually perfectly collinear $(\mathrm{r}=0.9989)$. The market scope variable, $\mathrm{USS}_{\mathrm{it}}$, and scope interaction term, $\mathrm{XAUS}_{\mathrm{it}}$, are also highly intercorrelated $(\mathrm{r}=0.9137)$.

INSERT TABLE 3 


\section{IV.3. $\underline{\text { Parameter Estimates }}$}

Table 4 presents the three stage least square estimates of the twelve parameters (eight coefficients for the firm fixed effects and four coefficients for the scale variable, two scope variables and their interaction) obtained using the 83 observations from the unbalanced panel available for estimation of the average variable cost model (2). The dependent variable of (2) is the natural logarithm of average variable cost (LAVC). Note that since it is expressed relative to revenues, this log-transformed variable is less than zero, reflecting the fact that average variable cost (AVC) is always less than one.

\section{INSERT TABLE 4}

Referring to column (1) of Table 4, we see that the estimate of the coefficient for scale variable, $\left(\beta_{1}-1\right)$, has the expected negative sign but is less than its estimated standard error. The coefficient for the quadratic scale term $\left(\beta_{2} / 2\right)$ is also negative and less than its standard error. The negative sign of $\beta_{2} / 2$ implies that over the considerable range of scale represented in our panel data, AVC is everywhere decreasing with increases in scale. A Wald test (EViews 2000, pp. 352$356)$ indicated that the null hypothesis that $\left(\beta_{2} / 2\right)=0$ is not be rejected $(p=0.7589)$. However, another Wald test indicated that the null hypothesis of constant returns $\left[\left(\beta_{i}-1\right)=0,\left(\beta_{2} / 2\right)=0\right]$ can be decisively rejected $(\mathrm{p}<0.0001)$.

The coefficient estimates for the scope variables ( $\gamma$ and $\delta$, respectively) in the full model (Column (1), Table 4) are both positive (and statistically highly significant), indicating that AVC increases as the share of gross income contributed by either U.S. operations or advertisingrelated services rises. The former effect is almost eighty percent greater than the latter. However, what is especially noteworthy is that the coefficient for the interaction of the two scope variables $(\theta)$ has a negative sign and is more than four times greater than its standard error. If the effects of 
the two scope variables were independent of one another, we would expect the estimate of $\theta$ to be zero. That does not appear to hold for these data, and indeed, the interaction effect of the two scope variables on total costs appears to be in the opposite direction from that of their individual effects. This result is consistent with the view firms may realize cost economies through the joint production of both advertising and marketing services. Apparently, the coordination economies accompanying the pursuit of the strategy of "one-stop shopping" are not completely bargained away in negotiations with client about compensation and service levels. The coefficients for the fixed firm effects are in all cases at least twice their standard errors.

Given the collinearity of linear (LWGI) and quadratic terms $\left((\mathrm{LWGI})^{2}\right)$ of the scale variable noted earlier, we omitted the latter and re-estimated the model with only the linear term included. The results are shown in Column (2) of Table 4. It is immediately apparent that signs of all of the coefficients remain unchanged but the magnitude and precision of the estimates has increased considerably. The coefficient on LWGI increases markedly in absolute magnitude by a factor of more than thirty and is now more than four times its estimated standard error. The coefficients for the two scope variables, USS and ADS, each increase in magnitude by about ten percent and the precision of these estimates also improves modestly. The coefficient for the interaction of the two scope variables remains negative but increases in absolute magnitude by about twenty percent. The precision of this estimate also increases modestly. In this simpler specification, the estimates of all eight coefficients for the fixed firm effects decrease algebraically, but their precision increases dramatically, the estimates now all being at least seven times their estimated standard errors.

With three stage least squares, the usual goodness-of-fit statistics such as adjusted $\mathrm{R}^{2}$ are not well-defined. As an alternative summary indicator of fit, we regressed the fitted values of 
LACR on their observed values using the parameter estimates reported in Column (2) of Table 4. This yields a value of $\mathrm{R}^{2}$ equal to .657 . We conclude that dropping the quadratic scale term from (2) results in an adequate specification of the behavior of average variable costs here. Based on the parameter estimates from Column (2) of Table 4, we now proceed to investigate scale and scope effects.

\section{ESTIMATES OF SCALE AND SCOPE ECONOMIES}

\section{V.1. Scale Economies}

Earlier in II.2, we discussed the concept of global or ray returns to scale (RRS) as one possible measure of size-related economies. See (3) for the definition. RRS is the ratio of average variable cost to marginal cost for the firm's total gross income, holding fixed its mix of outputs which we have operationalized in terms of shares of gross income contributed by different markets and lines of services.

As noted above, in our preferred model specification $\beta_{2}=0$ and hence the expression for RRS (5) simplifies to:

$$
\mathrm{RRS}=\mathrm{AVC} / \mathrm{MC}=1 / \beta_{1}
$$

From Table 4, we have $\left(\hat{\beta}_{1}-1\right)=-0.0247$ and hence $\hat{\beta}_{1}=0.9753$. Substituting the estimate for $\hat{\beta}_{1}$ in $(5 \mathrm{a})$, we find $\mathrm{RRS}=1.0253$.

Note that RRS is not firm-specific. If we interpret our results as representing a point on the long-run average cost curve (Pindyck and Rubinfield 1995) for a typical firm in the advertising and marketing services industry, then given that RRS is slightly greater than one, we may infer that firms in this industry are operating on a long-run cost curve that is subject to very slight economies of scale. It also bears noting that the alternative hypotheses of constant returns to scale $\left(\beta_{1}=1\right.$ and hence $\left.R R S=1\right)$ was decisively rejected by a Wald test $(p<0.0001)$. 
We also computed the indices of product-specific scale economies defined in IV.2 as the returns to scale associated with two alternative strategies for expanding a firm's scale: (a) extending its line of business from advertising to marketing service, SCL(MS) and (b) extending the markets it serves from the domestic to overseas, $\mathrm{SCL}(\mathrm{OV})_{\mathrm{i}}$. Recall each is defined as the ratio of average incremental cost to marginal cost for the additional volume gained by extending the firm's service mix or market reach. Firm-specific values of both indices were computed for each year using the parameter estimates for our preferred model (with $\beta_{2}=0$ ) in (8) and (11). The results are summarized in columns (1) and (2) of Table 5.

\section{INSERT TABLE 5}

Across all eight firms and time period for which data were available, diseconomies of scale prevailed for extending lines of business from advertising to marketing services. As may be seen in column (1) of Table 5, the mean and median for this index were both less than one: 0.282 and 0.239 , respectively, for SCL(MS) . The range of values for the 83 observations of this index was from 0.052 (MIN) to 0.609 (MAX). For each of the eight firms, a separate Wald test was performed of the null hypothesis that returns to scale were constant (i.e., AIC $=\mathrm{MC}$ and SCL $=1$ ). For all eight firms, the null hypothesis of constant returns was strongly rejected ( $\mathrm{p}<$ $0.0001)$.

In the cases of the four firms where the extension of markets served from the U.S. to overseas could be validly assessed, diseconomies of scale were also uniformly observed for all time periods for which data were available. The mean and median for this scale index (SCL(OV), column (2) of Table 5)) were again both less than one (0.492 and 0.501, respectively), as were the extreme observed values $(\mathrm{MIN}=0.333)$ and $(\mathrm{MAX}=0.654)$. Here 
again, Wald tests indicated that the null hypothesis of constant returns was strongly rejected $(\mathrm{p}<$ 0.0001) for all (four) firms.

Whereas our estimates indicated global scale economies $(\mathrm{RRS}=1.053)$, product-specific diseconomies of scale for both extension of lines of business and expansion of markets served. None of the calculated values of either SCLMS or SCLOV summarized in Table 5 exceeded unity. To see why global scale economies are consistent with product-specific scale diseconomies in this context, consider Eq. (8) for SCL(MS) which, with $\beta_{2}=0$, may readily be shown to simplify to:

$$
\operatorname{SCL}(M S)=\frac{\left\lceil\operatorname{TVC}\left(\mathrm{Y}_{\mathrm{i}}\right)-\mathrm{TVC}\left(\mathrm{Y}_{\mathrm{i}}\right)\right\rfloor}{\operatorname{TVS}(\mathrm{Yi})} \frac{1}{\beta 1}
$$

The first term on the right-hand side of $(8 a)$ is the estimated incremental total cost of producing marketing services separately as a proportion of the total costs of jointly producing both advertising and marketing services. The second term in (8a) is the index of global scale economies (5), ray returns to scale (RRS $=1 / \beta_{1}$ ). Since our estimate of $\beta_{1}=0.975$, productspecific diseconomies will obtain unless the incremental total cost of producing the addition to the line of business as a proportion of the total cost of producing both lines of services is equal to or greater than $\beta_{1}=0.975$. Inasmuch as the maximum value of marketing service's share of firm gross income in our sample was 0.610 , it is not surprising that the latter condition does not hold here for the addition of market services. Hence we find the latter strategy is accompanied by diseconomies of scale $\left(\mathrm{SCL}(\mathrm{MS})_{\mathrm{i}}<1\right)$. A similar analysis accounts for why extending market coverage overseas was also found to involve diseconomies of scale $\left(\mathrm{SCL}(\mathrm{OV})_{\mathrm{i}}<1\right)$. The maximum value of the overseas market's share of firm total gross income for the four firms included in our analysis of SCL(OV) was 0.640 . 
To gain insight into the sources of variation in the magnitude of scale diseconomies across firms and times, we regressed the scale indices on the four scale, scope, and scope interaction variables affecting the scale indices, as indicated by equations (8) and (11). Given that these expressions indicate that the relationship between the product-specific scale indices and the measures of scale and scope variables is nonlinear, linear and quadratic terms were included in the regressions for the three scale and scope variables. The results are summarized in columns (1) and (2) of Table B1 in Appendix B, where the standard partial regression coefficients are shown for the aforementioned set of explanatory variables. The estimated standard partial regression coefficients measure the change in a scale index as a fraction of its standard deviation associated with a change of one standard deviation in the explanatory variables (Ezekiel and Fox 1959). The regressions are intended to serve only as a means of describing how scale economies covary with measures that reflect the size and composition of a firm's output. Below we highlight the key features of the relationships with firm size and the scope variable relevant to each type of product-specific scale economy. Details for the full set of covariates are given in columns (1) and (2) of Table B1 in Appendix B. In interpreting these results, the reader should be mindful of our basic finding that diseconomies of scale prevailed across all firms and over all time periods for both SCL(MS) and SCL(OV).

Consider first the results pertaining to variation in scale diseconomies relating to firms' broadening their lines of business to include marketing services as well as advertising-related ones. The relationship between SCL(MS) and the firm size (WGI = worldwide gross income in constant dollars) was found to be non-monotonic (concave from below) with SCL(MS) increasing over a small range of values of firm size: from WGI' MIN of $\$ 484.7$ million to a gross income level of $\$ 767.7$ million, which is well below WGI's median value of $\$ 1599.0$ 
million. The range from MIN to the inflexion point encompassed almost twenty-eight percent of our sample of 83 observations. Beyond the inflexion point, SCL(MS) declined with further increases in size for the remaining sixty-two percent of observations. Not unexpectedly, SCL(MS) decreases at a slightly decreasing rate (convex from below) as advertising service's share of firm gross income (ADS) increases over the entire range of observations.

Turning to the variability in the diseconomies of scale associated with extending coverage from the U.S. to overseas markets, we find that SCL(OV) bears no reliable relationship with firm size. While the sample of relevant observations $(n=44)$ here was restricted to only four of the eight firms, it nonetheless encompassed a wide range of values of the firm size variable (WGI; $\mathrm{MIN}=\$ 603.1$ mill., $\mathrm{MAX}=6296.3$ mill.). As is to be expected, $\mathrm{SCL}(\mathrm{OV})$ decreases at a slightly decreasing rate (convex from below) with increases in the U.S. share of firm gross income (USS) over the range of available observations.

\section{V.2. $\underline{\text { Scope Economies }}$}

The possible advantages accruing to a firm with a broad product line rather than a narrow one, or cost advantages arising from serving the global market rather than just the U.S. market may be assessed by estimating returns to scope. As defined in (12) and (14), our index of scope economies represents the percentage cost savings realized from the joint production of some mix of services (or for a combination of markets) over the costs of producing the services separately (or for the markets separately). In the case of two products (or markets), global and productspecific scope economies are identical.

Substituting the parameter estimates for our preferred model (with $\beta_{2}=0$ ) into (13) and (15), we calculated for all firms and time periods scope economy indices which estimate the percent savings for joint production as compared to stand-alone production of: (a) advertising- 
related and other marketing services $\left(\mathrm{RSP}(\mathrm{LB})_{\mathrm{i}}\right)$, and (b) U.S. and overseas markets (RSP(GL) $)$. The results are summarized in columns (4) and (5) of Table 5.

It is immediately apparent from Table 5 that economies of scope were realized by all firms in all time periods from joint as opposed to separate production for both diversification strategies. The cost savings were small but uniformly positive. The median savings for either expanding the line of services offered or extending the scope of markets served was less than two per cent, with the variation in savings distributed over a limited range of less than one percent to under four percent. For the case of the joint production of advertising and marketing services, the estimated cost savings was less than one percent for only about six percent of the sample observations. Realization of only minimal cost savings was more frequent for the joint production of services for the U.S. and overseas markets; the estimated cost savings was less than one percent for nineteen percent of the sample observations. However, the null hypotheses that the joint costs equal the sum of the stand-alone costs $(\mathrm{RSP}(\mathrm{LB})=0$ or $\mathrm{RSP}(\mathrm{GL})=0$ ) was strongly rejected $(\mathrm{p}<0.0001)$ for all eight firms for both indices of scope economies.

As with the indices of scale economies, we analyzed variation in the magnitude of scope economies by regressing each of the indices of scope economies on the four scale, scope, and scope interaction variables. Here we limit the discussion to focus on relations involving the size and relevant scope variable. Detailed results for the full set of covariates are presented in columns (3) and (4) of Table B1 in Appendix B.

The estimated relationship between scope economies associated with joint production of advertising and marketing services and firm size was found to be J-shaped (convex from below) with the minimum level of RSP(LB) occurring when firm size was $\$ 813.4$ mill. Thus RSP(LB) fell as firm size increased for almost a quarter of the sample observations and then increased 
over the subsequent range of observations which accounted for the remaining three-quarters of the sample observations.

The estimated relationship between SCL(LB) and the share of firm revenue arising from advertising services (ADS) was concave (from below). However, over the range of observations of RSP(LB) contained in the sample, RSP(LB) decreased monotonically as advertising share increased. That relationship is consistent with the expectation that as firms add marketing services to their prior line of advertising services, savings from the joint production of both increase with increases in the share of firm revenue realized from marketing services since the latter share equals (1-ADS).

In the case of the other dimension of scope (RSP(GL), the form of the relationship between firm size and savings from producing for both the U.S. and overseas markets jointly rather than separately was found to be J-shaped (convex from below), similar to the manner in which RSP(LB) and firm size were found to be related. RSP(GL) declined as size increased when gross income was $\$ 1,462.4$ million or less (which accounted for about forty-two percent of the observations) and then increased as firm size increased beyond that level for the remaining fifty-eight percent of the sample observations. For at least a majority of our sample of observations, both RSP(LB) and RSP(GL) increased as firm size increased. Thus, in contrast to Silk and Berndt's (1995) results for individual advertising agencies, we find no evidence of any tendency for large holding companies to over diversify. To the contrary, at low levels of firm size, scope economies appear to decrease with increases in firm size and hence small firms may be under diversified in the sense that greater scope economies could be realized were they able to achieve gross incomes above the inflexion point in J-shaped relationship between size and scope economies. 
Contrary to expectations, the parameter estimates for the relevant standardized partial regression coefficients indicated that RSP(GL) increased (rather than decreased) monotonically as share of firm revenue from U.S. operations (USS) increased (convex from below). This counterintuitive result may be accounted for by the presence of an influential cluster of observations for firms based outside the U.S. with extremely small shares of their gross income coming from U.S. operations, especially in the early years of the time series. When that set of observations was removed, the expected negative relationship between RSP(GL) and USS emerged.

\section{VI.DISCUSSION}

\section{VI.1. Scale and Scope Economies}

Our results suggest that the industry's long-run cost function is subject to very slight economies of scale. We also find that modest diseconomies of scale accompanied the broadening of lines of business (from advertising to marketing services) or market coverage (from the U.S. to overseas). Product-specific scale diseconomies were shown to be consistent with overall or global scale economies in this context, given the limited level of global scale economies available and the composition of firm income with respect to lines of business and markets served. Taken together, these findings do not point to any substantial level of potential scale economies that remains to be exploited by the largest firms in this industry. Such findings are to be expected in a highly competitive industry with relatively low fixed costs.

However, two cautions should be noted. First, recall that the parameter estimate for the quadratic term in our cost model turned out to be non-significant. Hence, we have been unable to learn much about the shape of the long-run cost curve or how firms might be arrayed along it. Second, we have not attempted to model the adjustment processes surrounding mergers and 
acquisitions and that omission may have clouded our results. In particular, the adjustment costs associated with digesting mergers and acquisitions could manifest themselves in our empirical analyses as diseconomies of scale. See Johnson and Simon (1970) for a provocative but now dated study of advertising agency mergers and acquisitions.

Our estimates of scope economies indicate that a small cost advantage, typically only one to two percent, is realized through the joint rather than separate production of advertising and marketing services and for the domestic and overseas markets. Obviously this is a crude partitioning of the global market and a more fine-grained decomposition would be preferable, especially one that separated the overseas market into European and Asian components. A more detailed disaggregation of firm revenue shares with respect to both lines of business and markets served would allow the scope and interaction variables to be defined and measured in terms of specific combinations of services and markets. These issues are deserving of further research.

We also note the possible threats to the validity of statistical conclusions posed by currencies fluctuations, cross-national differences in accounting standards, and by intra-firm and inter-firm differences in accounting methods. The adequacy of our estimates of firm fixed effects as controls for those factors remains to be assessed.

\section{VI.2. The Advantage of the Holding Company Form of Organization}

In earlier studies we investigated the role of scale and scope economies in the domestic operations of U.S. agencies (Schamalensee, Silk, and Bojanek 1983 and Silk and Berndt 1993, 1995). Using a proxy for average cost (employees per dollar of gross income) in a cross sectional analysis of 400 agencies, Silk and Berndt (1993) found that both scale and particularly scope economies (measured by shares of output in different advertising media) were highly significant in the operations of U.S. agencies. They estimated the minimum efficient size of a domestic 
agency to be \$3-4 million of gross income in 1987 dollars (\$6-8 million in 2001 dollars). Of the approximately 10,000 firms comprising the industry in 1987, 200- 250 had domestic gross incomes at that level or larger and therefore had output levels and media-mixes sufficient to take full advantage of all the size-related efficiencies seemingly available at that time.

The 2001 worldwide gross income of the smallest of the eight holding companies included in this study (Cordiant) was more than a hundred times greater than the aforementioned estimate of minimum efficient size of a domestic agency; the largest in our present study (Omnicom) was almost eight hundred times greater. The overwhelming difference in scale raises the question: what, exactly, are the advantages of the holding company structure not available in a single agency structure?

Fine et al. (2003, p. 123) suggests that the answer lies in cost economies and the ability to cope with the constraints imposed by the account conflicts. Our results are consistent with such advantages in the sense that we find that holding companies appear to be operating in the vicinity of a point on the long-run cost curve subject to scale economies, albeit quite modest ones, and are generally diversified to an extent that permits realization of positive scope economies, again of quite limited magnitude. Furthermore, our analyses of how variability in scope economies is related to firm size indicated that holding companies are not subject to the excessive diversification which Berndt and Silk (1995) found in their study of individual advertising agencies and which they attributed to the constraints on growth imposed by conflict policy and the bundling of services. Thus, the holding company appears to be a form of organization which circumvents the institutional constraints which restricted the growth and diversification opportunities of the traditional full service advertising agency. 
Holding companies are publicly-owned enterprises and no explicit attention has been given to that condition in the present study. Research underway by von Nordenflycht (2003) emphasizes the advantages of holding companies with respect to access to capital markets and the ability to exploit size as a proxy for capabilities. Interestingly, he finds no relationship between public vs. private agency ownership and winning awards for creativity.

\section{VI.3. Organization of the Advertising and Marketing Services Industry}

Historically, the U.S. advertising agency business has been characterized as a classic example of an industry with minimal barriers to entry, low fixed costs and geographically dispersed demand-i.e., roughly forty to forty-five per cent of total U.S. advertising expenditures are accounted for by local, as opposed to national advertisers. Silk and Berndt (1995) argued that the structure of demand and costs in the U.S. advertising agency business conforms to the conditions Macdonald and Slivinski (1989) showed were required for an industry to sustain an equilibrium with diversified firms. A highly diverse and unconcentrated size structure has long persisted in the U.S. advertising agency industry and over time, it has become more geographically dispersed (King, Silk, and Kettelhohn 2003). That size structure has enabled holding companies to cherrypick from a large and varied pool of mid-sized and small U.S.-based agencies (and human capital) in making hundreds of acquisitions over the past several decades.

More than a decade and a half ago, Sheth (1986) predicted that three global firms would eventually dominate the industry. ${ }^{4}$ Silk and King (2003) found that the concentration level in the U.S. advertising agency business, as traditionally defined, rose during the 1990's-although not to the extent that has sometimes been suggested. Their estimates indicate that the major advertising agency brands controlled by the eight largest holding companies represented about a

\footnotetext{
${ }^{4}$ Also see Sheth and Sisodia (2002).
} 
quarter of the total gross income earned from traditional advertising-related services in 2001 by all U.S. agencies. How the industry structure in other countries that represent smaller regional and local markets has been affected by globalization and diversification awaits further study. The shifts in client demand toward more global and diversified advertising and marketing services has, of course, also raised barriers to entry and fixed costs for suppliers of those services. The nature of the industry equilibrium that can be sustained under these altered conditions is also an important topic for further research.

\section{CONCLUSION}

This paper reported an econometric analysis of cost economies experienced by holding companies operating in the global advertising and marketing services business. Treating holding companies as multi-product firms, we estimated a translog model of costs. A firm's total variable costs are affected by its scale, scope of its lines of business and market coverage, and the interaction of the latter two dimensions of scope. Our results indicate that the long-run cost function for firms in the global advertising and marketing services business is subject to very slight scale economies. Growth in volume obtained through either extending the lines of business to include marketing services in addition to advertising services or expanding market coverage overseas from the U.S. were subject to modest levels of product-specific diseconomies of scale. These findings do not point to any substantial level of potential scale economies that remains to be exploited by the largest firms in this industry. Such findings are to be expected in a highly competitive industry with relatively low fixed costs.

Small scope economies amounting to a few percentage points of cost savings accompany diversification through both extending lines of business and expanding market coverage. While small in percentage terms, in an industry where firms strive to achieve operating margins of 
fifteen percent and where income and costs are measured in billions, these economies (diseconomies) clearly matter. The institutional constraints, especially adherence to the industry norm of an agency not serving competing accounts, that limited the potential of traditional full service advertising agencies for growth and diversification appear to have been obviated by the holding company form of organization. 


\section{REFERENCES}

American Association of Advertising Agencies (1979), "A Practical Solution to Client-Agency Account Conflicts," New York, July.

Anholt, Simon (2000), “Updating the International Advertising Model,” Admap, No. 407 June), $18-21$.

Bagwell, Kyle (2002), "The Economic Analysis of Advertising," unpublished paper, Columbia University, August.

Bailey, Elizabeth E. and Ann F. Friedlander (1982), "Market Structure and Multiproduct Industries," Journal of Economic Literature, 20 (September), 1024-1048.

Berndt, Ernst R.(1991), The Practice of Econometrics. Reading, MA: Addison-Wesley.

Bower, Joseph L. and Sonja Ellingson Hunt, (2001) "WPP—Integrating Icons to Leverage Knowledge," Harvard Business School Case 9-396-249, November 14.

Cardona, Mercedes, M. (2002a), "Billings Lose Agency Value," Advertising Age, 73 (July 22), 6.

(2002b),"Ad Holding Company Model Defended at Conference," AdAge.Com accessed November 22, 2002 at http://adage.com/news.cms?newsId=36625.

Caves, Richard E. and Michael E. Porter (1977), "From Entry Barriers to Mobility Barriers: Conjectural Decisions and Contrived Deterrence to New Competition," Quarterly Journal of Economics, 91, 241-261.

.Doft, David B., Ashley M. Ammon, and Ken Gawrelski (2002), "The Evolution of Advertising 2003,” Equity Research, CIBC World Markets, New York, November 14.

Elliot, Stuart (2002), “Advertising's Big Four: Its Their World Now,” New York Times,(March 31), Section 3, 2 and 10.

Endicott, R. Craig (2002), “58 $8^{\text {th }}$ Annual Advertising Agency Report,” Advertising Age, 73, (April 22), 1 and S1-S21.

Eviews4 (2000), User's Guide. Irvine, CA: Quantitative Micro Software.

Ezekiel, Mordecai and Karl A. Fox (1959), Methods of Correlation and Regression Analysis, $3^{\text {rd }}$ ed. New York: Wiley.

Fine, Lauren Rich, Tom Deitz, Sara Gubins, Karl Choi, Stacy Fleck, and Di Howie (2003), "Advertising \& Marketing Services: Global Ad Primer," Global Securities Research \& Economics Group, Merrill Lynch, New York, February 20. 
Horsky, Sharon (2002), "The Changing Architecture of Advertising Agencies," unpublished paper, Arison School of Business, Herzliya, Israel, July.

Johnson, Harold W. and Julian L. Simon (1970), "The Success of Mergers of Advertising Agencies," in Julian L. Simon, Issues in the Economics of Advertising. Urbana, IL: University of Illinois Press, 139-144.

Johnson, Russ (1982), Marion Harper. Chicago: Crain Books.

Khermouch, Gerry (2003), “Interpulic Group: Synergy—or Sinkhole?” BusinessWeek, (April 21), 76-77.

Kim. Kwangmi Ko (1995), "Spreading the Net: The Consolidation Process of Large Transnational Advertising Agencies in the 1980s and Early 1990s," International Journal of Advertising, 14, No. 3, 195-217.

King, Charles King III, Alvin J. Silk, and Niels Kettelhohn (2003) "Knowledge Spillovers and Growth in the Disagglomeration of U.S. Advertising Agency Industry," Journal of Economics and Management Strategy, 12 (Fall), in press.

Lawrence, Robyn Griggs (2000), "Parents and Progeny,” Agency, 10 (Spring), 10-11.

MacDonald, Glenn M. and Alan Slivinski (1989), "The Simple Analytics of Competitive Equilibrium with Multiproduct Firms,” American Economic Review, 77 (December), 941-953.

Mandese, Joe (2002), "Consolidation or Consolation? Madison Avenue's Big Get Bigger," ADMAP, Issue 430 (July/August), p. 8.

Merron, Jeff (1999), "Putting Foreign Consumers on the Map: J. Walter Thompson's Struggle with General Motors' International Advertising Account in the 1920's," Business History Review, 73 (Autumn), 465-502.

Paul, Catherine J. Morrison (1999), Cost Structure and the Measurement of Economic Performance. Boston: Kluwer.

Paster, Harry (1981), "Measuring the Size of an Advertising Agency," American Association of Advertising Agencies Newsletter, (September), 2.

Pindyck, Robert S. and Daniel L. Rubinfield (1995), Microeconomics, $3^{\text {rd }}$ ed. Englewood Cliffs, NJ: Prentice-Hall.

Raynor, Michael E. and Joseph L. Bower (2001), "Lead from the Center: How to Manage Divisions Dynamically,” Harvard Business Review, 79 (May), 93-100.

Schmalensee, Richard L., Alvin J. Silk, and Robert Bojanek (1983), "The Impact of Scale and Media Mix on Advertising Agency Costs,” Journal of Business, 56 (October), 453-475. 
Schmidt, Peter (1975), "A Note on the Estimation of Seemingly Unrelated Regressions Using Unequal Numbers of Observations," unpublished paper, University of North Carolina.

Sheth, Jagdish N. (1986), "The Future of the Advertising Agency Business," Speech delivered at the Annual Meeting of the American Association of Advertising Agencies, March 10. and Rajendra Sisodia (2002), The Rule of Three. New York: Free Press.

Silk. Alvin J. and Ernst R. Berndt (1993), "Scale and Scope Effects on Advertising Agency Costs," Marketing Science, 12 (Winter), 53-72.

(1995), "Costs, Institutional Mobility Barriers, and Market

Structure: Advertising Agencies as Multiproduct Firsms," Journal of Economics and Management Strategy, 3 (Fall), 47-480.

and Charles King III (2003), "Changes in the Structure of U.S. Advertising Agency Industry," Working Paper, Harvard Business School, forthcoming.

von Nordenflycht, Andrew (2003), "The Rise of Global Advertising Holding Companies," unpublished paper, Sloan School of Management, M.I.T., February.

West, Douglas C. (1987), "From T-Square To T-Plan: The London Office of the J. Walter Thompson Advertising Agency," Business History, 29 (April), 199-217.

(1988), "Multinational Competition in the British Advertising Agency Business, 1936-1987,” Business History Review, 62 (Autumn), 467-501.

Weinstein, Arnold K. (1974), "The International Expansion of U.S. Multinational Advertising Agencies,” M.S.U. Business Topics, (Summer), 29-35.

Wooldridge, Jeffrey (2002), Econometric Analysis of Cross Section and Panel Data. Cambridge, MA: MIT Press. 
Table 1

CROSS SECTION OF FIRMS

\begin{tabular}{|c|c|c|c|c|}
\hline Firm & $\begin{array}{c}\text { Head- } \\
\text { quarters }\end{array}$ & \multicolumn{2}{|c|}{ Time Series } & $\begin{array}{l}2001 \text { World } \\
\text { Gross Income } \\
\text { (Millions Current \$ U.S.) }\end{array}$ \\
\hline $\begin{array}{l}\text { Cordiant } \\
\text { Communications } \\
\text { Group plc }\end{array}$ & London & $1998-2001$ & 4 & $\$ \quad 871.26$ \\
\hline Dentsu & Tokyo & $1989-2001$ & 13 & $2,417.7^{\mathrm{b}}$ \\
\hline $\begin{array}{l}\text { Grey Global Group } \\
\text { Inc. }\end{array}$ & New York & $1989-2001$ & 13 & $1,217.0$ \\
\hline Havas Advertising $^{\mathrm{c}}$ & $\begin{array}{l}\text { Levallois- } \\
\text { Perret }\end{array}$ & $1992-2001$ & 10 & $2,241.4$ \\
\hline Interpublic Group & New York & 1989-2001 & 13 & $6,726.8$ \\
\hline $\begin{array}{l}\text { Omnicom } \\
\text { Communications } \\
\text { Group Inc. }\end{array}$ & New York & $1989-2001$ & 13 & $6,889.4$ \\
\hline Publicis Groupe SA & Paris & $1989-2001$ & 13 & $2,718.9$ \\
\hline WPP Group plc & London & 1989-2001 & 13 & $5,791.7$ \\
\hline TOTAL & & & & $\$ 28,874.1$ \\
\hline
\end{tabular}

${ }^{\text {a }}$ Cordiant was taken over by WPP on August 1, 2003.

${ }^{\mathrm{b}}$ For fiscal year ending 3/31/02.

${ }^{c}$ Data for 1992-1994 are for Euro RSCG which then became Havas Advertising in 1995.

Source: Annual Reports. For non-U.S. firms, conversions to \$U.S. of gross income reported in other currencies were made at the daily average exchange rates for 2001. 


\begin{tabular}{|c|c|}
\hline Abbreviation & Definition \\
\hline WGI $_{\text {it }}$ & $\begin{array}{l}\text { World-wide gross income from commission and fees for agency } \mathrm{i} \text { in } \\
\text { year } \mathrm{t} \text { in millions of constant } \$ \text { U.S. } \mathrm{i}=1, \ldots, 8 ; \mathrm{t}=1989, \ldots, 2001 \text {. }\end{array}$ \\
\hline $\mathrm{LWGI}_{\mathrm{it}}$ & Natural logarithm of $\mathrm{WGI}_{\mathrm{it}}$. \\
\hline $\mathrm{TVC}_{\mathrm{it}}$ & Total variable operating costs in millions of constant $\$$ U.S. \\
\hline $\mathrm{AVC}_{\mathrm{it}}$ & Average variable operating costs, calculated as $\mathrm{TVC}_{\mathrm{it}} / \mathrm{WGI}_{\mathrm{it}}$. \\
\hline $\mathrm{LAVC}_{\mathrm{it}}$ & Natural logarithm of $\mathrm{AVC}_{\mathrm{it}}$. \\
\hline $\mathrm{ADS}_{\mathrm{it}}$ & $\begin{array}{l}\text { Share of } \mathrm{WGI}_{\mathrm{it}} \text { accounted for advertising-related services. The share } \\
\text { contributed by other marketing services is: }\left(1-\mathrm{ADS}_{\mathrm{it}}\right) \text {. }\end{array}$ \\
\hline $\mathrm{USS}_{\mathrm{it}}$ & $\begin{array}{l}\text { Share of } \mathrm{WGI}_{\mathrm{it}} \text { accounted for output sold in the U.S. market. The share } \\
\left.\text { for the overseas market is (1-USS }{ }_{\mathrm{it}}\right) \text {. }\end{array}$ \\
\hline $\mathrm{XAUS}_{\mathrm{it}}$ & Interaction term, $\mathrm{XAUS}_{\mathrm{it}}=\mathrm{ADS}_{\mathrm{it}} \mathrm{x} \mathrm{USS}_{\mathrm{it}}$. \\
\hline
\end{tabular}

* Annual reports for each of the firms were sources for the income and cost data used to compute the set of variables listed above. For non-U.S. firms, variables reported in foreign currencies were converted to U.S. dollars following the accounting convention of making the conversion of income and costs at the average daily exchange rate for each year. Quantities of current U.S. dollars were transformed into constant U.S. dollars using the GDP implicit price deflator. In cases where data for ADS and USS were not included in the annual reports, estimates found in the reports of financial analysts or in the annual issues of Advertising Age's "Agency Report," were used, where such data were available. 
Table 3

SUMMARY OF STATISTICS FOR REVENUE AND COST VARIABLES $(n=83)$

\begin{tabular}{|lrrr|r|c|}
\hline $\begin{array}{l}\text { Vari- } \\
\text { Able }\end{array}$ & Mean & Std. Dev. & Median & Max & Min \\
\hline $\mathrm{AVC}_{\text {it }}$ & 0.8491 & 0.0384 & 0.8478 & 0.9271 & 0.7489 \\
$\mathrm{WGI}_{i t}$ & 1932.928 & 1381.857 & 1598.954 & 6296.295 & 484.664 \\
$\mathrm{ADS}_{i t}$ & 0.7200 & 0.1340 & 0.7200 & 0.9471 & 0.3900 \\
USS $_{i t}$ & 0.3251 & 0.1854 & 0.3985 & 0.6383 & 0.0102 \\
XAUS $_{\text {it }}$ & 0.2179 & 0.1271 & 0.2306 & 0.4482 & 0.0073 \\
& & & & & \\
LAVC $_{i t}$ & -0.1664 & 0.0468 & -0.1651 & -0.0757 & -0.2892 \\
LWGI $_{i t}$ & 7.3415 & 0.6728 & 7.3771 & 8.7477 & 6.1835 \\
\hline
\end{tabular}

CORRELATION MATRIX

$$
(\mathrm{n}=83)
$$

\begin{tabular}{l|rrrrrr} 
& LAVC $_{\text {it }}$ & LWGI $_{\text {it }}$ & $\left(\text { LWGI }_{i t}\right)^{2}$ & USS $_{\text {it }}$ & ADS $_{\text {it }}$ & XAUS $_{\text {it }}$ \\
\hline LAVC $_{\text {it }}$ & 1.0000 & & & & & \\
LWGI $_{\text {it }}$ & -0.2439 & 1.0000 & & & & \\
$\left(\mathrm{LWGI}_{i t}\right)^{2}$ & -0.2437 & 0.9989 & 1.0000 & & & \\
USS $_{\text {it }}$ & 0.4289 & 0.3948 & 0.4002 & 1.0000 & & \\
ADS $_{\text {it }}$ & -0.0840 & -0.5275 & -0.5390 & -0.4024. & 1.0000 & \\
XAUS $_{\text {it }}$ & 0.4623 & 0.1312 & 0.1327 & 0.9137 & -0.0145 & 1.0000
\end{tabular}


Table 4

THREE-STAGE LEAST SQUARE PARAMETER ESTIMATES FOR ALTERNATIVE SPECIFICATIONS OF LOG AVERAGE COST MODEL

$$
(\mathrm{n}=83)
$$

\begin{tabular}{|c|c|c|c|}
\hline \multirow[b]{2}{*}{ Vaiable } & \multirow[b]{2}{*}{ Parameter } & \multicolumn{2}{|c|}{ Dependent Variable: $\mathrm{LAVC}_{\mathrm{it}}$} \\
\hline & & (Ratio of Paramet & $\begin{array}{l}\text { te } \\
\text { mptotic Std Error) }\end{array}$ \\
\hline & & (1) & (2) \\
\hline LWGI $_{\text {it }}$ & $\left(\beta_{\mathrm{i}}-1\right)$ & $\begin{array}{l}-0.008517 \\
(0.247)\end{array}$ & $\begin{array}{l}-0.024713 \\
(4.698)\end{array}$ \\
\hline$\left(\mathrm{LWGI}_{\mathrm{it}}\right)^{2}$ & $\beta_{2} / 2$ & $\begin{array}{l}-0.000705 \\
(0.307)\end{array}$ & \\
\hline $\mathrm{USS}_{\mathrm{it}}$ & $\gamma$ & $\begin{array}{l}0.579196 \\
(5.710)\end{array}$ & $\begin{array}{l}0.662785 \\
(6.406)\end{array}$ \\
\hline $\mathrm{ADS}_{\mathrm{it}}$ & $\delta$ & $\begin{array}{l}0.324241 \\
(6.196)\end{array}$ & $\begin{array}{l}0.363235 \\
(6.715)\end{array}$ \\
\hline XAUS $_{i}$ & $\theta$ & $\begin{array}{l}-0.636157 \\
(4.501)\end{array}$ & $\begin{array}{l}-0.763902 \\
(5.297)\end{array}$ \\
\hline $\begin{array}{l}\text { Firm-Specific } \\
\text { Intercept }\end{array}$ & $\ln \alpha_{\mathrm{i}}$ & & \\
\hline$i=1$ & & $\begin{array}{l}-0.327982 \\
(2.394)\end{array}$ & $\begin{array}{l}-0.278684 \\
(7.742)\end{array}$ \\
\hline $\mathrm{i}=2$ & & $\begin{array}{l}-0.382490 \\
(2.677)\end{array}$ & $\begin{array}{l}-0.332183 \\
(8.538)\end{array}$ \\
\hline$i=3$ & & $\begin{array}{l}-0.305785 \\
(2.220)\end{array}$ & $\begin{array}{l}-0.250309 \\
(7.364)\end{array}$ \\
\hline $\mathrm{i}=4$ & & $\begin{array}{l}-0.328578 \\
(2.376)\end{array}$ & $\begin{array}{l}-0.276019 \\
(8.793)\end{array}$ \\
\hline$i=5$ & & $\begin{array}{l}-0.387107 \\
(2.807)\end{array}$ & $\begin{array}{l}-0.327275 \\
(9.434)\end{array}$ \\
\hline$i=6$ & & $\begin{array}{l}-0.358471 \\
(2.574)\end{array}$ & $\begin{array}{l}-0.302363 \\
(9.124)\end{array}$ \\
\hline$i=7$ & & $\begin{array}{l}-0.355101 \\
(2.574)\end{array}$ & $\begin{array}{l}-0.305281 \\
(9.512)\end{array}$ \\
\hline$i=8$ & & $\begin{array}{l}-0.292106 \\
(2.095)\end{array}$ & $\begin{array}{l}-0.235310 \\
(7.146)\end{array}$ \\
\hline
\end{tabular}


Table 5

SUMMARY STATISTICS FOR ESTIMATES OF SCALE AND SCOPE ECONOMIES

\begin{tabular}{|c|c|c|c|c|}
\hline & \multicolumn{2}{|c|}{ Returns to Scale: AIC/MC } & \multicolumn{2}{|c|}{$\begin{array}{c}\text { Scope Economies: \% Cost } \\
\text { Savings from Joint Production } \\
\text { over Stand-Alone Production for: }\end{array}$} \\
\hline & $\begin{array}{c}\text { (1) } \\
\text { Extending Lines } \\
\text { of Business from } \\
\text { Advert. to Mktg. } \\
\text { Services } \\
\text { SCL(MS) }\end{array}$ & $\begin{array}{c}(2) \\
\text { Extending } \\
\text { Markets Served } \\
\text { from U.S. to } \\
\text { Overseas } \\
\text { SCL(OV) }\end{array}$ & $\begin{array}{c}\text { (3) } \\
\text { Advertising } \\
\text { and Mktg. } \\
\text { Services } \\
\text { RSP(LB) }\end{array}$ & $\begin{array}{l}\text { (4) } \\
\text { U.S. and } \\
\text { Overseas } \\
\text { Markets } \\
\text { RSP(GL)i }\end{array}$ \\
\hline Mean & 0.282 & 0.492 & 1.709 & 1.733 \\
\hline Std. Dev. & 0.146 & 0.073 & 0.521 & 0.920 \\
\hline Median & 0.239 & 0.501 & 1.713 & 1.777 \\
\hline Max & 0.609 & 0.654 & 3.755 & 3.688 \\
\hline Min & 0.052 & 0.333 & 0.518 & 0.152 \\
\hline $\begin{array}{l}\text { Number of } \\
\text { Observations }\end{array}$ & 83 & 44 & 83 & 83 \\
\hline $\begin{array}{l}\text { Number of } \\
\text { Firms }\end{array}$ & 8 & 4 & 8 & 8 \\
\hline
\end{tabular}




\section{APPENDIX A: DERIVATION OF INDICES OF SCALE AND SCOPE EFFECTS}

\section{A.1. Product-Specific Scale Economies}

\section{A.1.a. Advertising and Marketing Services as Separate Products}

Given that a firm is producing advertising-related services, we wish to measure the scale economies (or diseconomies) associated with adding other marketing services to its service mix. Following Bailey and Friedlander (1982, p.1030), we may define the returns to scale for this case as:

$$
\operatorname{SCL}(\mathrm{MS})_{\mathrm{i}}=\mathrm{AIC}_{\mathrm{im}} / \mathrm{MC}_{\mathrm{im}}
$$

where $\mathrm{AIC}_{\mathrm{im}}$ is the average incremental cost of producing the quantity $\mathrm{Y}_{\mathrm{im}}$ of marketing services in addition to its output of advertising-related services, $\mathrm{Y}_{\text {ia }}$.

$$
\mathrm{AIC}_{\mathrm{im}}=\left[\mathrm{TVC}\left(\mathrm{Y}_{\mathrm{i}}\right)-\mathrm{TVC}\left(\mathrm{Y}_{\mathrm{ia}}\right)\right] / \mathrm{Y}_{\mathrm{im}},
$$

where:

$$
\mathrm{Y}_{\mathrm{im}}=\left(1-\mathrm{P}_{\mathrm{ia}}\right) \mathrm{Y}_{\mathrm{i}}
$$

The numerator of the right hand side of (A2) is the difference between the total costs of producing both products jointly, $\mathrm{TVC}\left(\mathrm{Y}_{\mathrm{i}}\right)$, and the total cost of producing the advertising services separately, TVC( $\left.\mathrm{Y}_{\mathrm{i}}\right)$. For our translog cost model (1), TVC( $\left.\mathrm{Y}_{\mathrm{i}}\right)$ is:

$$
\operatorname{TVC}\left(\mathrm{Y}_{\mathrm{i}}\right)=\exp \left(\ln \alpha_{\mathrm{i}}+\beta_{1} \ln \mathrm{Y}_{\mathrm{i}}+1 / 2 \beta_{2}\left(\ln \mathrm{Y}_{\mathrm{i}}\right)^{2}+\gamma \mathrm{M}_{\mathrm{id}}+\delta \mathrm{P}_{\mathrm{ia}}+\theta \mathrm{M}_{\mathrm{id}} \mathrm{P}_{\mathrm{ia}}\right)
$$

Now if advertising services were produced separately, the volume of such services would remain unchanged (i.e., $\mathrm{Y}_{\mathrm{ia}}=\mathrm{P}_{\mathrm{ia}} \mathrm{Y}_{\mathrm{i}}$ ), but would now account for all of the output (i.e., $\mathrm{P}_{\mathrm{a}}=1$ ). We assume that the composition of the advertising services volume in terms of mix of production for the U.S. and overseas markets remains the same as for the firm as a whole, as given by the share, $\mathrm{M}_{\mathrm{id}}$ and (1- $\left.\mathrm{M}_{\mathrm{id}}\right)$, respectively. Substituting in (A4), we obtain:

$$
\operatorname{TVC}\left(\mathrm{Y}_{\mathrm{ia}}\right)=\exp \left(\ln \alpha_{\mathrm{i}}+\beta_{1} \ln \mathrm{P}_{\mathrm{ia}} \mathrm{Y}_{\mathrm{i}}+1 / 2 \beta_{2}\left(\ln \mathrm{P}_{\mathrm{ia}} \mathrm{Y}_{\mathrm{i}}\right)^{2}+(\gamma+\theta) \mathrm{M}_{\mathrm{id}}+\delta\right)
$$

The denominator in (A1) is the marginal cost defined as:

$$
\mathrm{MC}_{\mathrm{im}}=\partial \mathrm{TVC}\left(\mathrm{Y}_{\mathrm{i}}\right) / \partial \mathrm{Y}_{\mathrm{im}}
$$

Using (A4) and taking the partial derivative of $\mathrm{TVC}\left(\mathrm{Y}_{\mathrm{i}}\right)$ with respect to $\mathrm{Y}_{\mathrm{im}}$ we obtain:

$$
\begin{aligned}
\mathrm{MC}_{\mathrm{im}}=\left[\left\{\beta_{1}+\right.\right. & \left.\beta_{2} \ln \mathrm{Y}_{\mathrm{i}}\right\} \exp \left\{\ln \alpha_{\mathrm{i}}+\beta_{1} \ln \mathrm{Y}_{\mathrm{i}}+1 / 2 \beta_{2}\left(\ln \mathrm{Y}_{\mathrm{i}}\right)^{2}+\gamma \mathrm{M}_{\mathrm{id}}+\delta \mathrm{P}_{\mathrm{ia}}\right. \\
& \left.\left.+\theta \mathrm{M}_{\mathrm{id}} \mathrm{P}_{\mathrm{ia}}\right\}\right] /\left(1-\mathrm{P}_{\mathrm{ia}}\right) \mathrm{Y}_{\mathrm{i}}
\end{aligned}
$$


Substituting (A3), (A4), (A5) in (A2) for $\mathrm{Y}_{\mathrm{im}}, \mathrm{TVC}\left(\mathrm{Y}_{\mathrm{i}}\right)$, and $\mathrm{TVC}\left(\mathrm{Y}_{\mathrm{ia}}\right)$, respectively, and dividing by (A7) in (A1), we get:

$$
\begin{aligned}
& {\left[\exp \left\{\ln \alpha_{i}+\beta_{1} \ln Y_{i}+1 / 2 \beta_{2}\left(\ln \mathrm{Y}_{\mathrm{i}}\right)^{2} \gamma \mathrm{M}_{\mathrm{id}}+\delta \mathrm{P}_{\mathrm{ia}}+\theta \mathrm{M}_{\mathrm{id}} \mathrm{P}_{\mathrm{ia}}\right\}\right.} \\
& \left.-\exp \left\{\ln \alpha_{\mathrm{i}}+\beta_{1} \ln \left(\mathrm{P}_{\mathrm{ia}} \mathrm{Y}_{\mathrm{i}}\right)+1 / 2 \beta_{2}\left(\ln \mathrm{P}_{\mathrm{ia}} \mathrm{Y}_{\mathrm{i}}\right)^{2}+(\gamma+\theta) \mathrm{M}_{\mathrm{id}}+\delta\right\}\right]
\end{aligned}
$$

$\operatorname{SCL}(\mathrm{MS})_{\mathrm{i}}=$

$$
\begin{aligned}
& {\left[\{ \beta _ { 1 } + \beta _ { 2 } \operatorname { l n } Y _ { \mathrm { i } } \} \operatorname { e x p } \left\{\ln \alpha_{\mathrm{i}}+\beta_{1} \ln \mathrm{Y}_{\mathrm{i}}+1 / 2 \beta_{2}\left(\ln \mathrm{Y}_{\mathrm{i}}\right)^{2}+\gamma \mathrm{M}_{\mathrm{id}}+\delta \mathrm{P}_{\mathrm{ia}}\right.\right.} \\
& \left.\left.+\theta \mathrm{M}_{\mathrm{id}} \mathrm{P}_{\mathrm{ia}}\right\}\right]
\end{aligned}
$$

\section{A.1.b. Markets Served as Separate Products}

The product-specific index of scale economies, $\mathrm{SCL}_{\mathrm{io}}$ associated with extending operations from the U.S. market (d) to the overseas market (o) is defined as $\mathrm{SCL}_{\mathrm{i}}$, the ratio of average incremental cost, $\mathrm{AIC}_{\mathrm{i}}$, to the marginal cost, $\mathrm{MC}_{\mathrm{io}}$ of producing the volume sold in the overseas market (o) in addition to that sold in the U.S. market (d):

$$
\mathrm{SCL}(\mathrm{OV})_{\mathrm{i}}=\mathrm{AIC}_{\mathrm{io}} / \mathrm{MC}_{\mathrm{io}},
$$

$\mathrm{AIC}_{\mathrm{io}}$ is defined as the incremental cost of adding volume sold in the overseas market to the costs incurred by a firm previously producing only for the U.S. market:

$$
\operatorname{AIC}_{\text {io }}=\left[\operatorname{TVC}\left(\mathrm{Y}_{\mathrm{i}}\right)-\mathrm{TVC}\left(\mathrm{Y}_{\mathrm{id}}\right)\right] / \mathrm{Y}_{\mathrm{io}},
$$

where:

$$
\mathrm{Y}_{\mathrm{io}}=\left(1-\mathrm{M}_{\mathrm{id}}\right) \mathrm{Y}_{\mathrm{i}}
$$

TVC $\left(\mathrm{Y}_{\mathrm{i}}\right)$ is the total variable cost of producing the volume sold in both the domestic and overseas markets and is given by (A4).

$\operatorname{TVC}\left(\mathrm{Y}_{\text {id }}\right)$ is the total variable cost of producing only the volume sold in U.S. market $\left(Y_{i d}=M_{i d} Y_{i}\right)$ and $Y_{i o}=\left(1-M_{i d}\right) Y_{i}$ is output sold overseas. $M_{i o}$ is marginal cost and defined as $\partial \mathrm{TVC}\left(\mathrm{Y}_{\mathrm{i}}\right) / \partial \mathrm{Y}_{\mathrm{io}}$. If output for the overseas market were produced separately, the quantity required for that segment would remain unchanged (i.e., $\mathrm{Y}_{\mathrm{ia}}=\mathrm{P}_{\mathrm{ia}} \mathrm{Y}_{\mathrm{i}}$ ), but would now account for all of the output (i.e., $\mathrm{P}_{\mathrm{a}}=1$ ). We assume that the composition of the advertising services volume in terms of mix of production of advertising and marketing services remains the same as before for the firm as a whole, as given by the share, $M_{i d}$ and $\left(1-M_{i d}\right)$, respectively. Substituting in (A4), we obtain:

$$
\operatorname{TVC}\left(\mathrm{Y}_{\mathrm{id}}\right)=\exp \left\{\ln \alpha_{\mathrm{i}}+\beta_{1} \ln \left(\mathrm{M}_{\mathrm{id}} \mathrm{Y}_{\mathrm{i}}\right)+1 / 2 \beta_{2}\left(\ln \mathrm{M}_{\mathrm{id}} \mathrm{Y}_{\mathrm{i}}\right)^{2}+(\delta+\theta) \mathrm{P}_{\mathrm{ia}}+\gamma\right\}
$$


The denominator in (A1) is the marginal cost defined as:

$$
\mathrm{MC}_{\mathrm{io}}=\partial \mathrm{TVC}\left(\mathrm{Y}_{\mathrm{i}}\right) / \partial \mathrm{Y}_{\mathrm{io}}
$$

Using (A4) and taking the partial derivative of $\operatorname{TVC}\left(\mathrm{Y}_{\mathrm{i}}\right)$ with respect to $\mathrm{Y}_{\mathrm{io}}$ we obtain:

$$
\begin{aligned}
\mathrm{MC}_{\mathrm{io}}=\left[\{ \beta _ { 1 } + \beta _ { 2 } \operatorname { l n } \mathrm { Y } _ { \mathrm { i } } \} \operatorname { e x p } \left\{\ln \alpha_{\mathrm{i}}+\beta_{1} \ln \mathrm{Y}_{\mathrm{i}}+1 / 2 \beta_{2}\left(\ln \mathrm{Y}_{\mathrm{i}}\right)^{2}+\gamma \mathrm{M}_{\mathrm{id}}+\delta \mathrm{P}_{\mathrm{ia}}\right.\right. \\
\left.\left.+\theta \mathrm{M}_{\mathrm{id}} \mathrm{P}_{\mathrm{ia}}\right\}\right] /\left(1-\mathrm{M}_{\mathrm{id}}\right) \mathrm{Y}_{\mathrm{i}}
\end{aligned}
$$

Substituting (A11), (A4), (A12) in (A10) for $\mathrm{Y}_{\mathrm{io}}, \mathrm{TVC}\left(\mathrm{Y}_{\mathrm{i}}\right)$, and $\mathrm{TVC}\left(\mathrm{Y}_{\mathrm{io}}\right)$, respectively, and dividing by (A14) in (A9), we get:

$$
\begin{aligned}
& {\left[\exp \left\{\ln \alpha_{\mathrm{i}}+\beta_{1} \ln \mathrm{Y}_{\mathrm{i}}+1 / 2 \beta_{2}\left(\ln \mathrm{Y}_{\mathrm{i}}\right)^{2} \gamma \mathrm{M}_{\mathrm{di}}+\delta \mathrm{P}_{\mathrm{ia}}+\theta \mathrm{M}_{\mathrm{id}} \mathrm{P}_{\mathrm{ia}}\right\}\right.} \\
& \left.-\exp \left\{\ln \alpha_{\mathrm{i}}+\beta_{1} \ln \left(\mathrm{M}_{\mathrm{id}} \mathrm{Y}_{\mathrm{i}}\right)+1 / 2 \beta_{2}\left(\ln \mathrm{M}_{\mathrm{id}} \mathrm{Y}_{\mathrm{i}}\right)^{2}+(\delta+\theta) \mathrm{P}_{\mathrm{ia}}+\gamma\right\}\right]
\end{aligned}
$$

$\operatorname{SCL}(\mathrm{OV})_{\mathrm{i}}=$

$$
\begin{aligned}
& {\left[\{ \beta _ { 1 } + \beta _ { 2 } \operatorname { l n } \mathrm { Y } _ { \mathrm { i } } \} \operatorname { e x p } \left\{\ln \alpha_{\mathrm{i}}+\beta_{1} \ln \mathrm{Y}_{\mathrm{i}}+1 / 2 \beta_{2}\left(\ln \mathrm{Y}_{\mathrm{i}}\right)^{2}+\gamma \mathrm{M}_{\mathrm{id}}+\delta \mathrm{P}\right.\right.} \\
& \left.\left.+\theta \mathrm{M}_{\mathrm{id}} \mathrm{P}_{\mathrm{ia}}\right\}\right]
\end{aligned}
$$

\section{A.2. Global Scope Economies}

\section{A.2.a. Advertising and Marketing Services as Separate Products}

We wish to measure the cost savings (or dissavings) that may arise when the two lines of business (i.e., advertising versus marketing services) that constitute the firm's service mix are produced jointly in the same organization rather than separately in separate organizations, each producing a different lines of business. For this case, returns to scope $\left(\mathrm{RSPLB}_{\mathrm{i}}\right)$ or the percentage cost savings realized from joint versus individual production is:

$$
\operatorname{RSP}(L B)_{i}=\left[\operatorname{TVC}\left(\mathrm{Y}_{\mathrm{ia}}\right)+\operatorname{TVC}\left(\mathrm{Y}_{\mathrm{im}}\right)-\mathrm{TVC}\left(\mathrm{Y}_{\mathrm{i}}\right)\right] / \operatorname{TVC}\left(\mathrm{Y}_{\mathrm{i}}\right)
$$

where $\mathrm{TVC}\left(\mathrm{Y}_{\mathrm{ia}}\right)$ and $\mathrm{TVC}\left(\mathrm{Y}_{\mathrm{im}}\right)$ are the costs of producing advertising (denoted by the subscript a) and marketing services separately $(\mathrm{m})$, respectively, and $\mathrm{TVC}\left(\mathrm{Y}_{\mathrm{i}}\right)$ is the cost of producing those services jointly.

If advertising services were produced separately, then the volume of such services would remain unchanged (i.e., $\mathrm{Y}_{\mathrm{ia}}=\mathrm{P}_{\mathrm{ia}} \mathrm{Y}_{\mathrm{i}}$ ) but that volume would account for all of the output of the specialized organization (i.e, $\mathrm{P}_{\mathrm{ia}}=1$ ). We assume that the volume of both the specialized organizations with respect to the shares of output produced for the U.S. and overseas markets remain the same as for the firm under joint production, i.e., $\mathrm{M}_{\mathrm{id}}$, and $\left(1-\mathrm{M}_{\mathrm{id}}\right)$, respectively. 
Applying these assumptions to our translog cost model (1), we find the total variable cost of producing advertising services separately to be:

$$
\operatorname{TVC}\left(\mathrm{Y}_{\mathrm{ia}}\right)=\exp \left\{\ln \alpha_{\mathrm{i}}+\beta_{1} \ln \mathrm{P}_{\mathrm{ia}} \mathrm{Y}_{\mathrm{i}}+1 / 2 \beta_{2}\left(\ln \mathrm{P}_{\mathrm{ia}} \mathrm{Y}_{\mathrm{i}}\right)^{2}+(\gamma+\theta) \mathrm{M}_{\mathrm{id}}+\delta\right\}
$$

Next we derive the total variable cost of producing marketing services separately, $\operatorname{TVC}\left(\mathrm{Y}_{\mathrm{im}}\right)$. The volume of that output is $\mathrm{Y}_{\mathrm{im}}=\left(1-\mathrm{M}_{\mathrm{ia}}\right)$, but $\mathrm{P}_{\mathrm{ia}}=0$, since only marketing services are produced. Inserting these assumptions into the translog cost model (1), we find:

$$
\operatorname{TVC}\left(\mathrm{Y}_{\mathrm{im}}\right)=\exp \left\{\ln \alpha_{\mathrm{i}}+\beta_{1} \ln \left(1-\mathrm{P}_{\mathrm{ia}}\right) \mathrm{Y}_{\mathrm{i}}+1 / 2 \beta_{2}\left(\ln \left(1-\mathrm{P}_{\mathrm{ia}}\right) \mathrm{Y}_{\mathrm{i}}\right)^{2}+\gamma \mathrm{M}_{\mathrm{id}}\right\}
$$

As before, the total variable cost of joint production, $\mathrm{TVC}\left(\mathrm{Y}_{\mathrm{I}}\right)$, is given by $(\mathrm{A} 4)$.

Substituting (A17), (A18), and (A4) in (A16) for TVC( $\left.Y_{i a}\right), \operatorname{TVC}\left(Y_{i m}\right)$, and TVC( $\left.Y_{i}\right)$, respectively, we get:

$$
\begin{aligned}
& {\left[\exp \left\{\ln \alpha_{\mathrm{i}}+\beta_{1} \ln \mathrm{P}_{\mathrm{ai}} \mathrm{Y}_{\mathrm{i}}+1 / 2 \beta_{2}\left(\ln \mathrm{P}_{\mathrm{ia}} \mathrm{Y}_{\mathrm{i}}\right)^{2}+(\gamma+\theta) \mathrm{M}_{\mathrm{id}}+\delta\right\}\right]} \\
& +\left[\exp \left\{\ln \alpha_{\mathrm{i}}+\beta_{1} \ln \left(1-\mathrm{P}_{\mathrm{ia}}\right) \mathrm{Y}_{\mathrm{i}}+1 / 2 \beta_{2}\left(\ln \left(1-\mathrm{P}_{\mathrm{ia}}\right) \mathrm{Y}_{\mathrm{i}}\right)^{2}+\gamma \mathrm{M}_{\mathrm{id}}\right\}\right]
\end{aligned}
$$

$\operatorname{RSP}(\mathrm{LB})_{\mathrm{i}}=$ $-1$

$$
\left[\exp \left\{\ln \alpha_{i}+\beta_{1} \ln Y_{i}+1 / 2 \beta_{2}\left(\ln Y_{i}\right)^{2}+\gamma M_{i d}+\delta P_{i a}+\theta M_{i i} P_{i a}\right\}\right]
$$

\section{A.2.b. Markets Served as Separate Products}

For the alternative split based on market served, returns to scope, $\mathrm{RSPMS}_{\mathrm{i}}$, the percentage cost savings gained from joint versus separate production is:

$$
\left.\operatorname{RSP}(M S)_{i}=\left[\operatorname{TVC}\left(\mathrm{Y}_{\mathrm{id}}\right)+\operatorname{TVC}\left(\mathrm{Y}_{\mathrm{io}}\right)-\mathrm{TVC}\left(\mathrm{Y}_{\mathrm{i}}\right)\right] / \operatorname{TVC}\left(\mathrm{Y}_{\mathrm{i}}\right)\right]
$$

Following similar reasoning to that discussed above with reference to the costs of split production of advertising and marketing services, we obtain the following expressions for the total variable costs of separating production for the U.S. and overseas markets, TVC $\left(\mathrm{Y}_{\mathrm{id}}\right)$ and TVC( $\left.\mathrm{Y}_{\mathrm{io}}\right)$, respectively:

$$
\begin{aligned}
& \operatorname{TVC}\left(\mathrm{Y}_{\mathrm{id}}\right)=\exp \left\{\ln \alpha_{\mathrm{i}}+\beta_{1} \ln \mathrm{M}_{\mathrm{id}} \mathrm{Y}_{\mathrm{i}}+1 / 2 \beta_{2}\left(\ln \mathrm{M}_{\mathrm{id}} \mathrm{Y}_{\mathrm{i}}\right)^{2}+\gamma+(\delta+\theta) \mathrm{P}_{\mathrm{ia}}\right\} \\
& \operatorname{TVC}\left(\mathrm{Y}_{\mathrm{io}}\right)=\exp \left\{\ln \alpha_{\mathrm{i}}+\beta_{1} \ln \left(1-\mathrm{M}_{\mathrm{id}}\right) \mathrm{Y}_{\mathrm{i}}+1 / 2 \beta_{2}\left(\ln \left(1-\mathrm{M}_{\mathrm{id}}\right) \mathrm{Y}_{\mathrm{i}}\right)^{2}+\delta \mathrm{P}_{\mathrm{ia}}\right\}
\end{aligned}
$$


Substituting (A21), (A22), and (A4) for TVC( $\left(\mathrm{Y}_{\mathrm{id}}\right), \operatorname{TVC}\left(\mathrm{Y}_{\mathrm{io}}\right)$, and $\mathrm{TVC}\left(\mathrm{Y}_{\mathrm{i}}\right)$, respectively, in (A20), we obtain:

$$
\begin{aligned}
& {\left[\exp \left\{\ln \alpha_{\mathrm{i}}+\beta_{1} \ln \mathrm{M}_{\mathrm{id}} \mathrm{Y}_{\mathrm{i}}+1 / 2 \beta_{2}\left(\ln \mathrm{M}_{\mathrm{id}} \mathrm{Y}_{\mathrm{i}}\right)^{2}+\gamma+(\delta+\theta) \mathrm{P}_{\mathrm{ia}}\right\}\right] } \\
+\left[\exp \left\{\ln \alpha_{\mathrm{i}}+\beta_{1} \ln \left(1-\mathrm{M}_{\mathrm{id}}\right) \mathrm{Y}_{\mathrm{i}}+1 / 2 \beta_{2}\left(\ln \left(1-\mathrm{M}_{\mathrm{id}}\right) \mathrm{Y}_{\mathrm{i}}\right)^{2}+\delta \mathrm{P}_{\mathrm{ia}}\right\}\right] & -1 \\
\operatorname{RSP}(\mathrm{GL})_{\mathrm{i}}= &
\end{aligned}
$$

$\left[\exp \left\{\ln \alpha_{\mathrm{i}}+\beta_{1} \ln \mathrm{Y}_{\mathrm{i}}+1 / 2 \beta_{2}\left(\ln \mathrm{Y}_{\mathrm{i}}\right)^{2}+\gamma \mathrm{M}_{\mathrm{id}}+\delta \mathrm{P}_{\mathrm{ia}}+\theta \mathrm{M}_{\mathrm{id}} \mathrm{P}_{\mathrm{ia}}\right\}\right]$ 


\section{APPENDIX B: STANDARDIZED REGRESSIONS RELATING SCALE AND SCOPE INDICES TO FIRM VARIABLES}

Each of the four product-specific indices of scale and scope economies summarized in Table 5 were separately regressed on the four size, share, and share interaction variables affecting the indices, as given by equations (8), (11), (13), and (15) which define the indices. Inasmuch as those expressions suggest that the relationship are nonlinear, we both linear and quadratic terms were included in the regressions for the three size and share variables. To facilitate comparisons across the regressions, all dependent and explanatory variables were scaled in units of the sample values of their standard deviations. Table B1 below presents the set of estimated standard partial regression coefficients for each regression. Standard partial regression coefficients measure the change in a scale index, expressed as a proportion of the sample value of its standard deviation, associated with a change of one standard deviation in an explanatory variable (Ezekiel and Fox 1959. Given the panel structure of our data, parameter estimates were obtained by treating each of the four equations as a set of seemingly unrelated regressions (SUR), one per firm. The intercept term was allowed to vary across firms (and treated as fixed effects) while the coefficients for the explanatory variables were assumed to be equal across firms. In the interests of conserving space, estimates of the intercept terms are not shown. 
Table B1

STANDARDIZED REGRESSIONS FOR SCALE AND SCOPE INDICES

\begin{tabular}{|c|c|c|c|c|}
\hline & \multicolumn{4}{|c|}{ Dependent Variable } \\
\hline & \multicolumn{2}{|c|}{ Returns to Scale: AIC/MC } & \multicolumn{2}{|c|}{$\begin{array}{l}\text { Scope Economies: \% Cost } \\
\text { Savings from Joint Production } \\
\text { over Stand-Alone Production for: }\end{array}$} \\
\hline & $\begin{array}{l}\text { (1) } \\
\text { Extending Lines } \\
\text { of Business from } \\
\text { Advert. to Mktg. } \\
\text { Services } \\
\text { SCL(MS) }\end{array}$ & $\begin{array}{c}\text { (2) } \\
\text { Extending } \\
\text { Markets Served } \\
\text { from U.S. to } \\
\text { Overseas } \\
\text { SCL(OV) it }\end{array}$ & $\begin{array}{l}\text { (3) } \\
\text { Advertising } \\
\text { and Mktg. } \\
\text { Services } \\
\text { RSP(LB) }\end{array}$ & $\begin{array}{c}\text { (4) } \\
\text { U.S. and } \\
\text { Overseas } \\
\text { Markets } \\
\text { RSP(GL) }\end{array}$ \\
\hline $\begin{array}{l}\text { Explanatory } \\
\text { Variable }\end{array}$ & \multicolumn{4}{|c|}{$\begin{array}{l}\text { Standardized Regression Coefficients } \\
\text { (Ratio of Coefficient to Standard Error) }\end{array}$} \\
\hline $\mathrm{LWGI}_{\mathrm{it}}$ & $\begin{array}{c}0.139 \\
(9.847)\end{array}$ & $\begin{array}{l}-0.033 \\
(1.486)\end{array}$ & $\begin{array}{l}-1.442 \\
(2.266)\end{array}$ & $\begin{array}{l}-0.791 \\
(2.810)\end{array}$ \\
\hline$\left(\mathrm{LWGI}_{\mathrm{it}}\right)^{2}$ & $\begin{array}{c}-0.155 \\
(10.273)\end{array}$ & $\begin{array}{c}0.038 \\
(1.550)\end{array}$ & $\begin{array}{l}1.594 \\
(2.386)\end{array}$ & $\begin{array}{l}0.804 \\
(2.604)\end{array}$ \\
\hline $\mathrm{ADS}_{\mathrm{it}}$ & $\begin{array}{c}-0.857 \\
(116.409)\end{array}$ & $\begin{array}{c}0.503 \\
(34.989)\end{array}$ & $\begin{array}{c}0.872 \\
(3.054)\end{array}$ & $\begin{array}{c}-1.754 \\
(12.969)\end{array}$ \\
\hline$\left(\mathrm{ADS}_{\mathrm{it}}\right)^{2}$ & $\begin{array}{c}0.091 \\
(15.923)\end{array}$ & $\begin{array}{c}-0.125 \\
(12.026)\end{array}$ & $\begin{array}{l}-2.184 \\
(8.812)\end{array}$ & $\begin{array}{c}1.268 \\
(10.814)\end{array}$ \\
\hline $\mathrm{USS}_{\text {it }}$ & $\begin{array}{c}0.605 \\
(45.922)\end{array}$ & $\begin{array}{c}-0.978 \\
(76.485)\end{array}$ & $\begin{array}{l}-4.005 \\
(8.697)\end{array}$ & $\begin{array}{c}1.323 \\
(5.182)\end{array}$ \\
\hline$\left(\mathrm{USS}_{\mathrm{it}}\right)^{2}$ & $\begin{array}{l}-0.019 \\
(5.177)\end{array}$ & $\begin{array}{c}0.120 \\
(12.449)\end{array}$ & $\begin{array}{c}1.086 \\
(9.799)\end{array}$ & $\begin{array}{c}0.994 \\
(15.332)\end{array}$ \\
\hline XAUS $_{\text {it }}$ & $\begin{array}{c}-0.355 \\
(33.118)\end{array}$ & $\begin{array}{c}0.037 \\
(4.435)\end{array}$ & $\begin{array}{c}2.165 \\
(5.853)\end{array}$ & $\begin{array}{c}0.268 \\
(1.310)\end{array}$ \\
\hline No. of Observ. & 83 & 44 & 83 & 83 \\
\hline No. of Firms & 8 & 4 & 8 & 8 \\
\hline Adjusted $\mathrm{R}^{2}$ & 0.999 & 0.999 & 0.712 & 0.890 \\
\hline $\begin{array}{l}\text { Std. Error Of } \\
\text { Estimate }\end{array}$ & 0.011 & 0.005 & 0.536 & 0.331 \\
\hline
\end{tabular}

